\title{
Review: \\ Genetic diversity of local and exotic cattle and their crossbreeding impact on the quality of Indonesian cattle
}

\author{
SUTARNO ${ }^{\eta}$, AHMAD DWI SETYAWAN \\ Department of Biology, Faculty of Mathematics and Natural Sciences, Sebelas Maret University. Jl. Ir. Sutami 36A Surakarta 57126, Central Java, \\ Indonesia. Tel./Fax.+62-271-663375, `email: nnsutarno@yahoo.com; volatileoils@gmail.com
}

Manuscript received: 3 September 2015. Revision accepted: 30 October 2015

\begin{abstract}
Sutarno, Setyawan AD. 2015. Genetic diversity of local and exotic cattle and their crossbreeding impact on the quality of Indonesian cattle. Biodiversita16: 327-354.Several species of cattle had been domesticated around the world, but only two species were farmed extensively, zebu cattle (Bos indicus) of the tropics and taurine cattle (Bos taurus) of the subtropical areas. Both of them had hundreds variety of offspring in the worlds. The third species of cattle that most widely farmed was Bali cattle (Bos javanicus), an indigenous cattle from Indonesia that was domesticated from wild banteng (Bos javanicus javanicus). Besides Bali cattle, Indonesia had also some local cattle as direct descendants of or as Crossbreeds of those three cattle. These cattle had been adapted to climatic conditions, feeds and diseases in Indonesia. Local zebu cattle that relatively pure were Peranakan Ongole (PO) or Ongole breeds and Sumba Ongole (SO). The main Crossbreed between zebu and Bali cattle was Madura cattle. The other well-known cattle of this were Aceh cattle, Pesisir cattle, Rancah cattle, Jabres cattle, Galekan cattle and Rambon cattle. Crossbreeds of taurine and zebu cattle generally produced calf that declining reproductive ability in generations. One fairly successful was Grati cattle or Holstein Freisian Indonesia (FHI) which was a crossbreed of Holstein Friesian and PO cattle. In recent decades, there were many crossbreed activities through artificial insemination between local cattle and taurine cattle to produce excellent beef cattle, mainly Simmental and Limousin. This activity was carried out widely and evenly distributed throughout Indonesia. It was conducted on all local cattle breeds and was strongly supported by local farmers. This crossbreeding activity was feared to change the genetic diversity of local Indonesia cattle, where the descendants could not adapt to the climatic conditions, feeds and localized diseases; and the ability of reproduction continues to decline in generations, there fore the availability of parental cattle should be maintained continuously. This crossbreed had produced some new breeds, among others Simpo (Simmental x PO), Limpo (Limousin x PO), Simbal (Simmental x Bali cattle), Limbal (Limousin x Bali cattle), and Madrasin or Limad (Limousin x Madura cattle). Male offsprings were sterile, while female offsprings had lower reproductive capacity than of the parent's. This lead to uncertainty over the guarantee of meeting the needs of protein (meat and milk) of Indonesian in the future, thus there was a need of regulation. On the other hand, in the grasslands of North Australia, the breeder had produced an eminent cattle breeds, namely Australian Commercial Cattle (ACC), from uncontrolled crossbreeds between different breedsof taurine and zebu cattle in the pasture, therefore this concerns ignored.
\end{abstract}

Key words: Crossbreeding, exotic cattle, genetic, local cattle, quality

\section{INTRODUCTION}

Cattle raising activities have been widely practiced in Indonesia since immemorial time. In the era of Hindu kingdoms, cattle is commonly awarded by kings to the Brahmin priests as an expression of gratitude, as shown in some inscriptions, such as the inscription of Muara Kaman, Kutai, East Kalimantan (4th century AD), the inscription of Tugu, Jakarta (mid-5thcenturyAD), and the inscription of Dinaya, Malang, East Java (760 AD). Cattle have long been used as draught animals in Indonesia. A relief on the wall of Borobudur temple, Magelang, Central Java (750 AD) showed a pair of zebu cattle (Bos indicus) is being used for plowing, while in Sukuh, Karanganyar, Central Java (mid-15th century AD), it is found a relief of cattle without humps or Bali cattle (Bos javanicus) with a big bells on the neck (Java: klonengan) as a characteristic of draught animals (Sutarno and Setyawan 2015). In the Islamic era, the need for cattle is increasing as the time of Eid al-Adha celebration by slaughtering livestock.
Moreover, in some areas the fasting of Ramadan and Eid al-Fitr were also celebrated by consuming livestock, for example Meugang tradition of Aceh which has been traced back to Sultan Iskandar Muda (1607-1636), thus encouraging the development of local Aceh cattle (Yunita 2012).

Cattle are the most important livestock commodities as a source of milk (dairy cattle), meat and leather (beef cattle), as well as draught animals. Cattle meet most of the world's needs for meat (50\%), leather (85\%) and milk (95\%) (Bappenas 2007; Umar 2009). In Indonesia, demand for meat and dairy cattle cannot be met from domestic stockbreeding, which can only fulfill approximately $75 \%$ and $20 \%$ of overall need respectively, so that Indonesia becomes a net importer of both commodities. From year to year, dependence on imports is increasing and without significant breakthrough, it is predicted that in the next 10 years the production of cattle in the country is only able to meet the half of needs. In the last three years (2013, 2014, 2015), before and after Eid al-Fitr is always turmoil in the 
domestic market related to the soaring price of beef cattle, due to lack of supplies. Demand for beef cattle increased because of the population growth, improved living standards, changing consumption patterns, and the presence of expatriates and foreign tourists who demand beef cattle with certain quality (DGLS 2010a; Khasrad and Ningrat 2010). The government has taken a long-term policy to achieve self-sufficiency in beef cattle based on domestic resources, but the effort is failed though it has been launched three times, in 2000, 2010, and 2014. The lack of breed quality, limited pastures and limited cattle feed are considered as the primary reason for the cause of this failure (DGLS 2010b; Mahbubi 2014).

This paper aims to review the genetic diversity of local and exotic cattle in Indonesia, the crossbreeds impact and conservation effort.

\section{WORLDWIDE CATTLE DOMESTICATION}

The domestication of wild banteng (Bos javanicus javanicus) into Bali cattle, which continue to be the main cattle in Indonesia until now, is a native of Indonesia's cultural heritage that should be preserved. The yielding of Bali cattle shows the potential of Indonesia to be an independent and sovereign country in terms of food. Cattle domestication process is mostly done in Europe and Asia but yields no sustainable offspring, except for only two species namely taurine cattle (Bos taurus) and zebu cattle (Bos indicus). Both are descendants of wild aurochs cattle (Bos primigenius), which is widespread in Asia, Europe, and North Africa at the end of the last glacial period $(12,000$ BP) (Felius et al. 2014). Taurine cattle domesticated between 10,300-10,800 BP at the border country of Turkey, Syria and Iraq (Helmer et al. 2005; Vigne 2011; Bollongino et al. 2012), while the zebu cattle domesticated in the Indus Valley on the desert edge of Mehrgarh, Baluchistan, Pakistan around 8000 BP (AjmoneMarsan et al. 2010; Chen et al. 2010). Domestication of species and a long history of migration, selection and adaptation have created a wide variety of breeds (Groeneveld et al. 2010). Based on the place of origin of domestication, the taurine cattle (without the hump) are sub-tropical cattle, with the main populations in Europe, North America and Australia. While, the zebu cattle (with the hump) are tropical cattle, with the largest population in India, Africa and Brazil. Each species of cattle have had hundreds of breeds, including the descent of its crossbreeds.

Bali cattle have been domesticated from wild banteng since c.a. 5000 BP (Payne and Hodges 1997). Bali cattle are the most successful domestication of cattle outside taurine and zebu cattle. When taurine and zebu cattle are the main world livestock, Bali cattle are the main livestock in Indonesia. However, the selection process of Bali cattle is relatively under-developed, that it has relatively same genetic as a wild banteng. Although, many Bali cattle is crossed with zebu cattle and, now, with taurine cattle, but the genetic proportion of its offspring is dominated by the exotic cattle, so it is no longer classified as Bali cattle, whilst the Bali cattle is relatively pure (Mohamed et al. 2009), except for Bali cattle in Malaysia which is a mixture of zebu and banteng with relatively balanced proportion (Nijman et al. 2003).

Domestication of the other cattle species was also conducted in Asia (Ho et al. 2008; Achilli et al. 2009). In Tibet, yak cattle (Bos grunniens) had been domesticated and able to adapt to high altitudes (Qiu et al. 2012) since c.a. 4500 BP (Payne and Hodges 1997). Gayal or mithun cattle (Bos frontalis) had been domesticated from wild gaur (Bos gaurus) (Uzzaman et al. 2014) on the border of northeast India, Bangladesh and Myanmar (Mason 1988; Payne and Hodges 1997). These species of Asia cattle hybridize with taurine and zebu cattle that are spreading more widely, resulting mixtures species that give a unique contribution to the world of livestock resources (Felius et al. 2014).

\section{INDONESIAN LOCAL CATTLE}

Indonesian local cattle has experienced a selection of various pressures of wet tropical climate, and an adaptation to low quality of feed, local parasitic and diseases, so it is a new adaptive phenotypes (Sutarno 2006). Besides Bali cattle, Indonesia has also several local cattle which are direct descendants of the Indian zebu cattle, the result of crossbreeding between zebu and Bali cattle, as well as crossbreeding with taurine cattle which is introduced latter (Martojo 2003; Johari et al. 2007). Primary crossbreeds between zebu or taurine cattle with banteng (or Bali cattle) produce fertile female and male sterile breeds (Lenstra and Bradley 1999). The Indonesian local cattle are generally a hybrid of zebu cattle with Bali cattle. Kikkawa et al. (2003) and Mohamad et al. (2009) found mtDNA of banteng on Indonesian zebu cattle, especially Madura cattle (56\%) and Galekan cattle (94\%). While Nijman et al. (2003), based on analysis of mtDNA and other genes, showed that Bali cattle in Indonesia comes purely from a banteng, while Bali cattle in Malaysia is a mixture of zebu and banteng.

Some local cattle belonging to zebu group are Peranakan Ongole (PO) cattle in Java, Pesisir cattle in West Sumatra, Aceh cattle in Aceh, and Sumba Ongole cattle on the island of Sumba. India is the center of zebu cattle genes (Nozawa 1979). Local cattle deriving from crossbreeds between zebu and Bali cattle includes Madura cattle in Madura and surroundings, Jabres cattle in Brebes, Rancah cattle in Ciamis and surroundings, Rambon cattle in Bondowoso and surroundings and the rare Galekan cattle in Trenggalek. In Indonesia, there are also local cattle which are considered as a crossbreed of two exotic cattle, zebu and taurine, namely Grati cattle in Pasuruan and surroundings, and now are more commonly known as Holstein Friesian (FH) Indonesia, which is a cross between FH male and PO female (Blakely and Bade 1998; Williamson and Payne 1980; Johari et al. 2007). According to Sutarno et al. (2015), based on studies of DNA microsatellites, Madura cattle have most different genetic characteristics than Bali cattle population (of Lombok and Sumbawa) and zebu cattle population (Aceh cattle and PO 
cattle).

Bali cattle, PO cattle, and Madura cattle become a mainstay to meet the needs of meat in Indonesia, while the Holstein Friesian cattle become a mainstay to meet the needs of milk (Okumura et al. 2007). Beef cattle population in Indonesia is currently about 12.3 million (BPS 2014), and dairy cattle is about 500,000 (DGLSAH 2014). These cattle consist of Bali cattle (33.73\%), PO cattle (23.88\%), Madura cattle $(5.16 \%)$, and others (13.45\%) (DGLS 2010b). The main concentration of the population of cattle is in Java (45\%), Sumatra (22\%), Bali and Nusa Tenggara (13\%), Sulawesi (13\%), and the rest in other islands (7\%). The population of cattle is slightly decreased after the financial crisis at the end of 1990 s, as many local cattle are consumed to replace the imported one. The consumption rate of local cattle exceeds the natural reproduction ability rate; there is a decrease in the number of calf born in the following years (Pamungkas et al. 2012).

Local cattle have proved that it can adapt to the local environment, including feed, water availability, climate and disease, but it generally has a lower productivity than the exotic cattle (ILRI 1995). Adapted animals have a production and reproduction regulating gene which are superior to environmental stress. Conservation of local cattle got a lot of challenges, especially since the rise of improving the calf quality by crossbreeding using frozen semen of exotic cattle, mainly Simmental and Limousin. Hybrid offsprings are high favorite for breeders because it is relatively high in daily weight gaining, although it requires higher production costs (Sutarno 2006; Sullivan and Diwyanto 2007). The efforts of crossbreeds are relatively successful for the same species of cattle, such as zebu and zebu, or taurine and taurine, but in crossbreeds of different species, it will produce calves of sterile males and fertile females with the ability of reproduction decreasing from generation to generation, thus the breeders must provide a new breeding male and female from time to time. The crossbreeding of local cattle with exotic cattle spreads widely without evaluation, control and ignoring the importance of local cattle as a unique germplasm. It is feared that it can lead to erosion of genetic resources towards extinction. Loss of important genes in cattle that have been locally adapted to local environmental conditions would be difficult, or even impossible, to be replaced. This has happened to many local cattle in India that have become extinct before it have been identified and utilized due to the many crossbreeds (Sodhi et al. 2006).

The weakness of cattle development in Indonesia is the poor quality of cattle genetics, lack of superior bulls, lack of farmers' ability in dealing with cattle breeding, and traditional method of stock raising (Atmakusuma et al. 2014). The development of local cattle is also facing challenges due to the rise of uncontrolled crossbreeding especially using artificial insemination methods and the pressures of other local cattle that are more superior, for example, the development of Pesisir cattle of West Sumatra is suppressed by superior Bali cattle. FAO (2000) has warned that livestock with the risk of extinction are in developing countries due to the high market demand, crossbreeding, breeds replacing and mechanization of farming activities where the use of cattle as draught animals is decreased (Figure 1).

\section{Bali Cattle}

Origin and distribution. Bali cattle (Bos javanicus) are the result of a direct domestication of wild banteng in Bali or Blambangan, East Java (MacHugh 1996; Verkaar et al. 2002; Martojo, 2003, 2012; Hardjosubroto 2004). Bali cattle spread widely throughout Indonesia, especially in South Sulawesi, Bali, East Nusa Tenggara, West Nusa Tenggara, Southeast Sulawesi and Lampung (Entwistle and Lindsay 2003; Sutarno 2010). These cattle are major genotypes in Eastern Indonesia (Pribadi et al. 2014). Bali cattle is not much raised in Central Java and West Java where the breeders prefers to raise goats (Capra hircus), which are an intermediary agent of malignant catarrhal, a deadly disease in Bali cattle calf. Bali cattle population is about 4.1 million (DGLS 2010b). These cattle are also found in northern Australia and Malaysia (Toelihere 2003). In northern Australia, Bali cattle live in wild as a banteng. They were from the 20 Bali cattle that were imported from Bali in 1849, and now the number is around $8,000-10,000$ (Bradshaw and Brook 2007). In comparison to Bali cattle, the genetic purity of these cattle comes near to the genetic purity of wild banteng in Java, since Bali cattle is allegedly received genetic mixing of zebu cattle (and now taurine). In Malaysia, Bali cattle began to be developed on a large scale and replace the local cattle of Kedah-Kelantan that has low productivity (Somarny et al. 2015). Bali cattle are the ancestor of most local cattle breeds in Indonesia. In fact, PO cattle which were considered as pure zebu cattle also have a gene introgression of Bali cattle, as well as Pesisir and Aceh cattle. Cattle that clearly and phenotypically pick Bali cattle gene are Madura, Rambon, Galekan, Jabres and Rancah cattle. But these cattle are genetically more close to the zebu cattle (Mohamed et al. 2009).

Physical characteristics. Bali cattle has similar physical characteristics to a wild banteng (Handiwirawan and Subandriyo 2004), but banteng is larger and more aggressive (Martojo 2003, 2012). The study of genetic diversity in Bali cattle and banteng is still limited (Kikkawa et al. 1995, 2003; Namikawa 1981; Nijman et al. 2003; Verkaar et al. 2003). Bali cattle have a great frame and solid muscle; adult male can weigh $600-800 \mathrm{~kg}$, while the female weigh is $500-600 \mathrm{~kg}$ (Martojo 2003). At the time of calf, cattle's body is brick red or golden red. Meanwhile, when adult, female cattle remain red brick, while the male cattle change to blackish at the age of 12-18 months. There are white on all four legs, from the knee to toes, buttock is white with clear boundaries and oval with black on tail tip (Williamson and Payne 1980). They have no humps, a small wattle and compact body. It has wide head, short, flat forehead and standing ears. The female horn is short and small, and the male horn is long and large heading to the front upper side and taper, with a slender neck. It has deep chest with powerful legs (Pane 1991; Susilorini 2010).

Advantages and disadvantages. Bali cattle has a very high reproductive ability, able to give birth every year, able to adapt to the marginal environment with dry climates, able to digest low quality of forage for example during the 

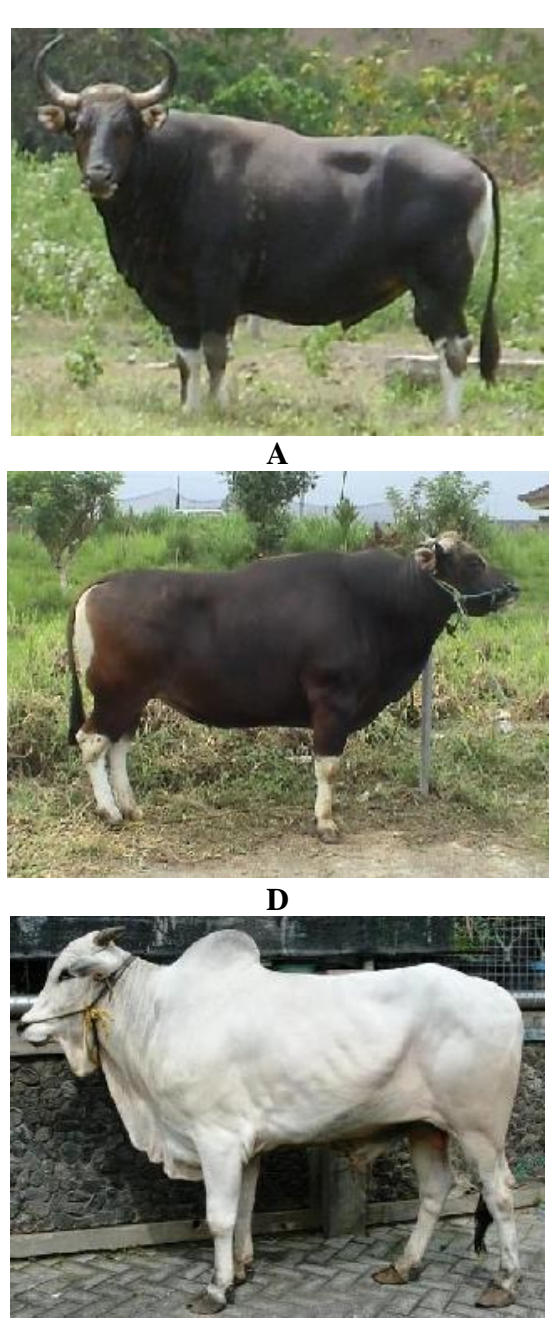

G
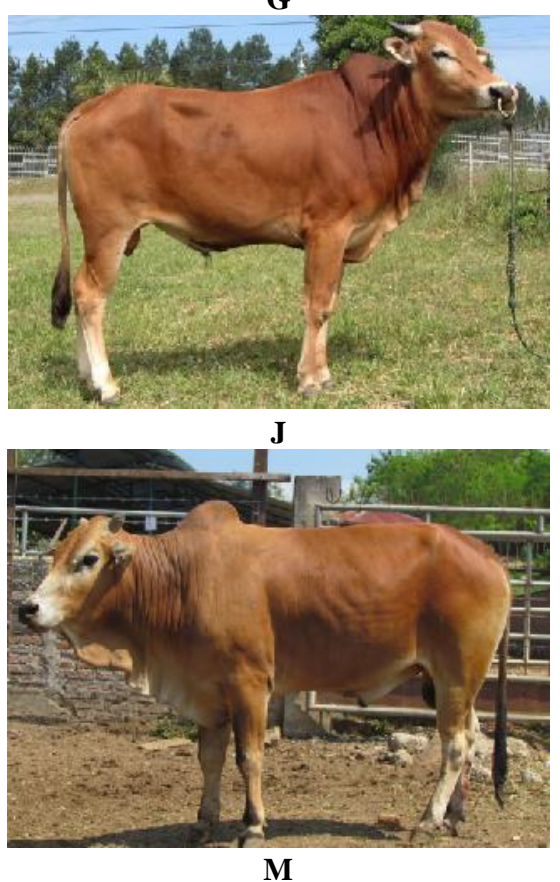
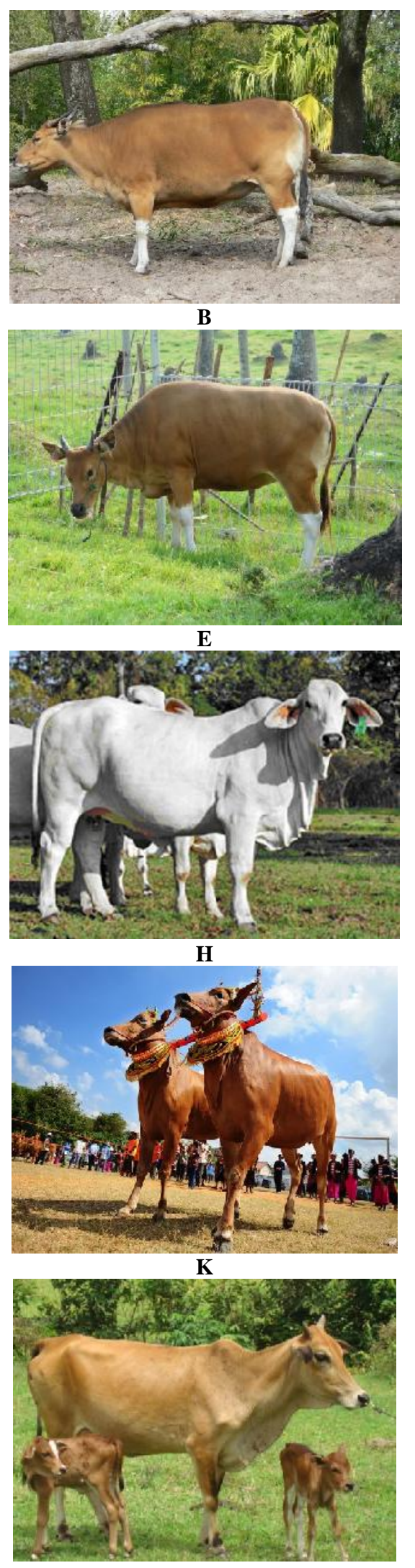

N
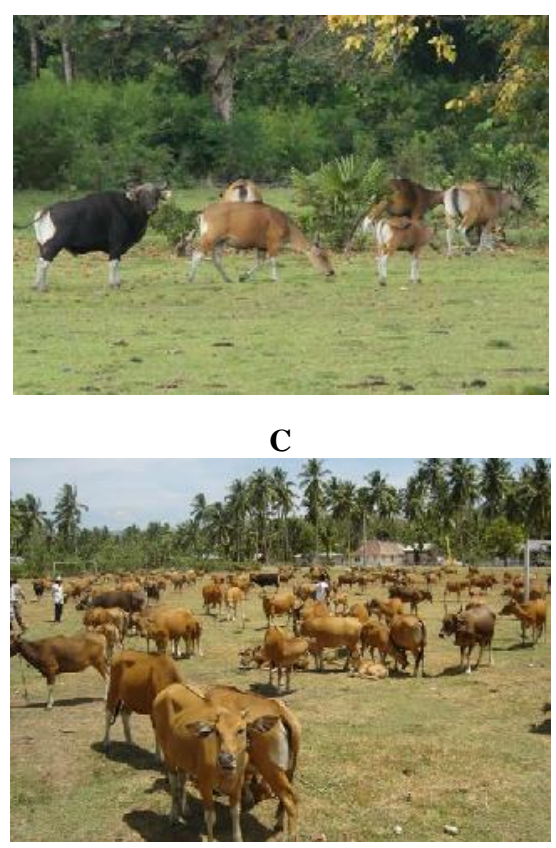

F
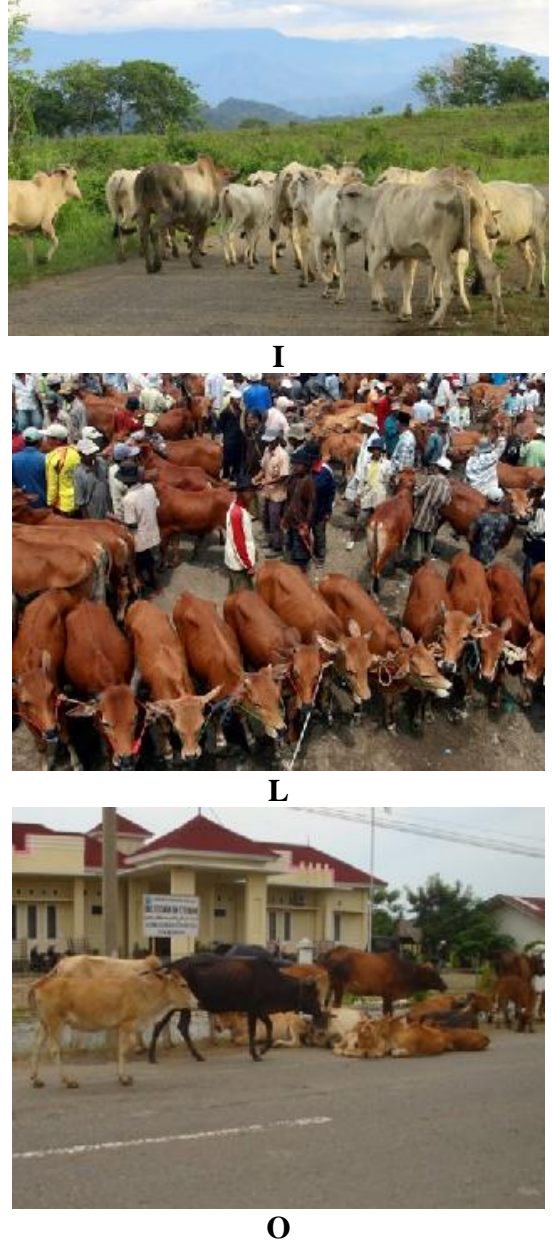

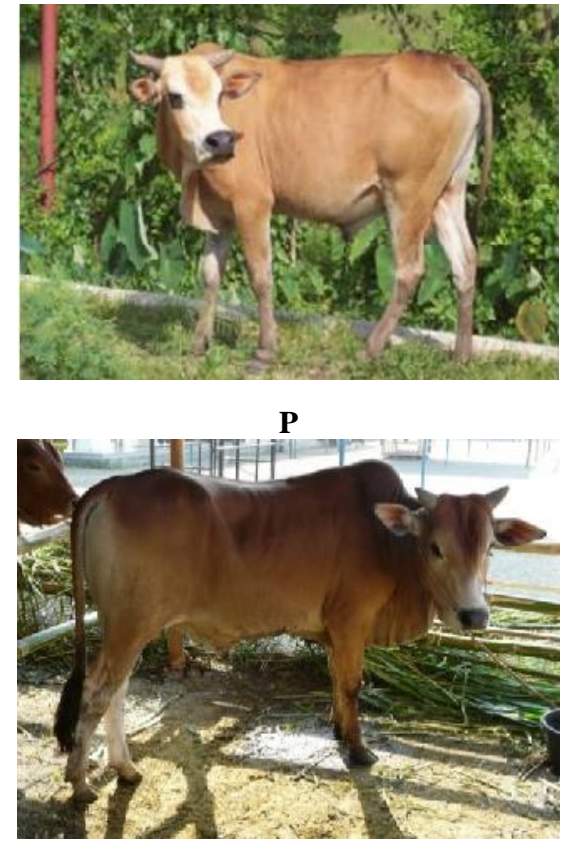

$\mathbf{S}$
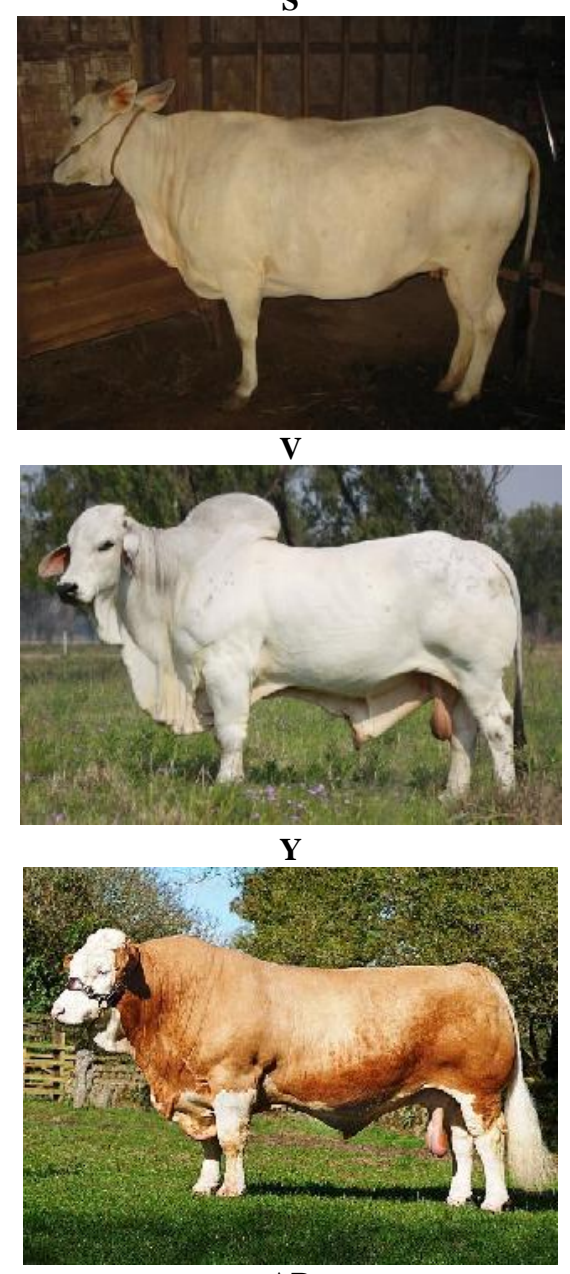

AB
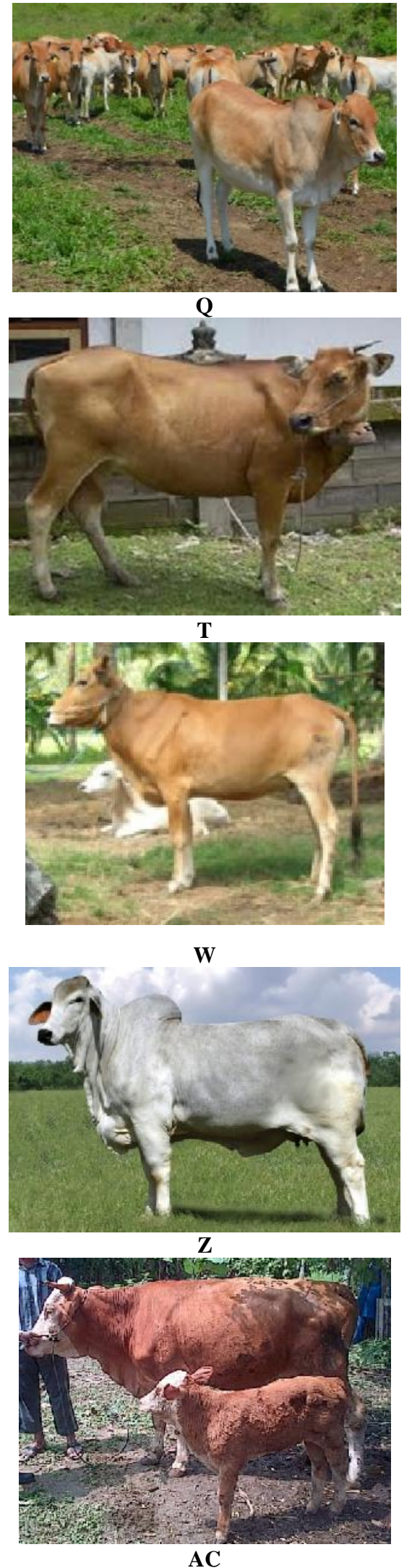
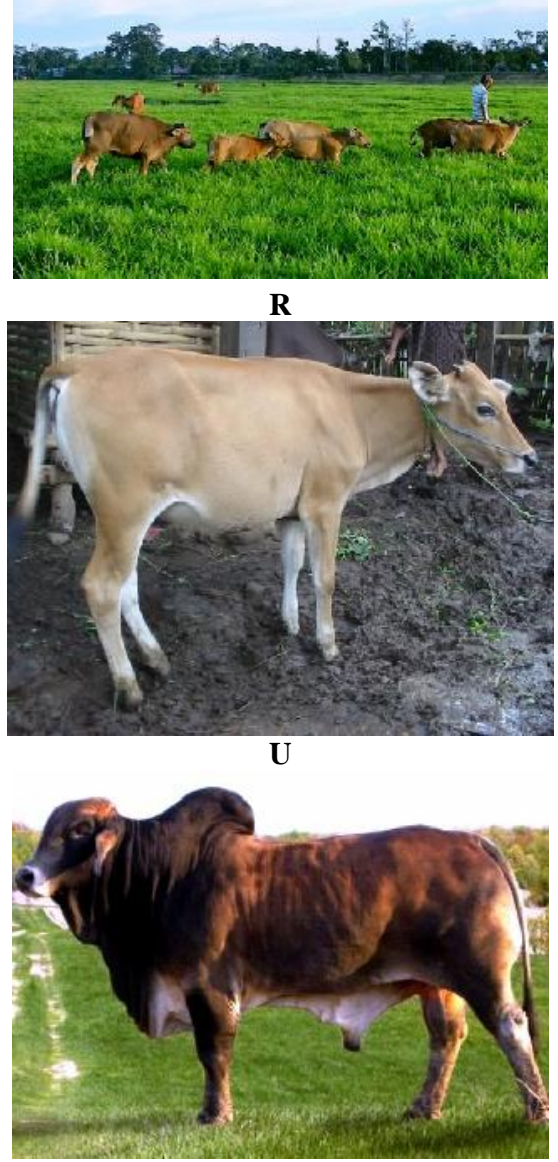

$\mathbf{X}$

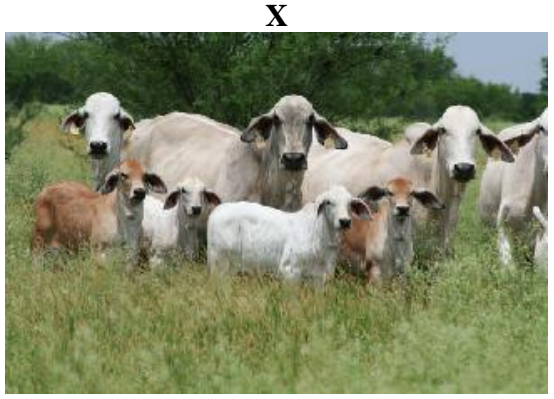

AA

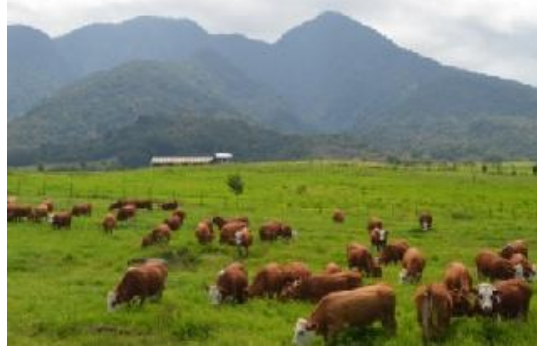

AD 


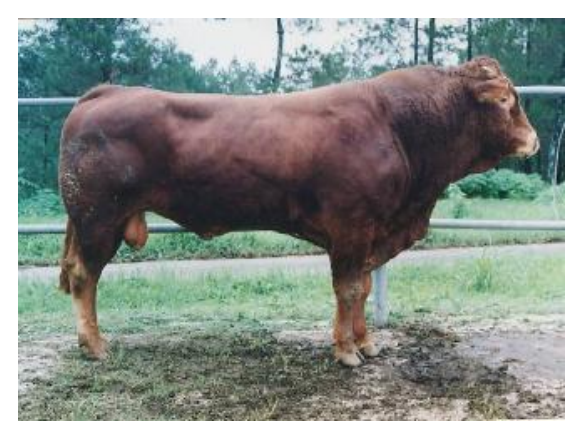

AE

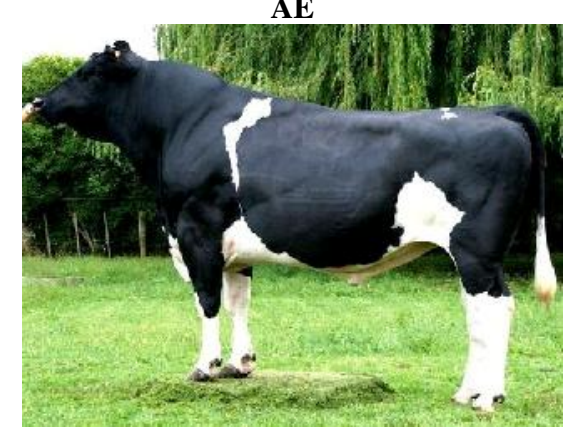

AH

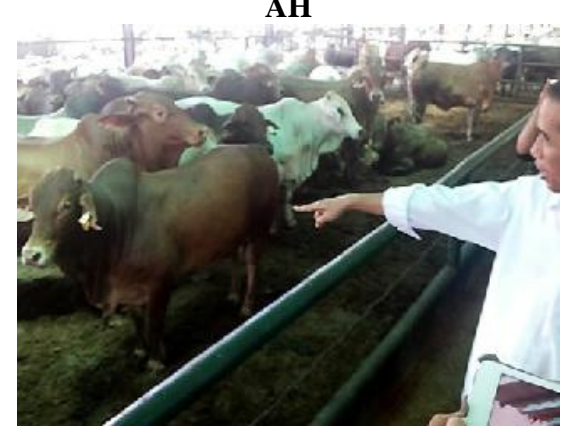

AK

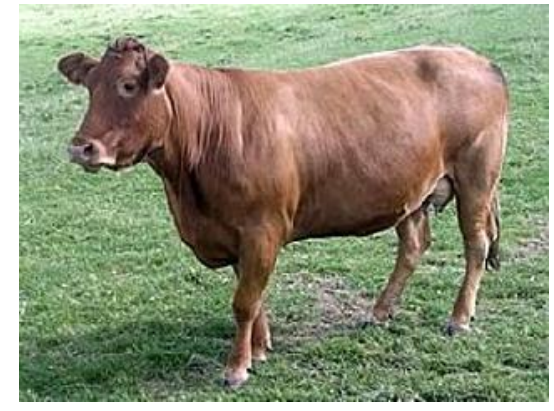

AF

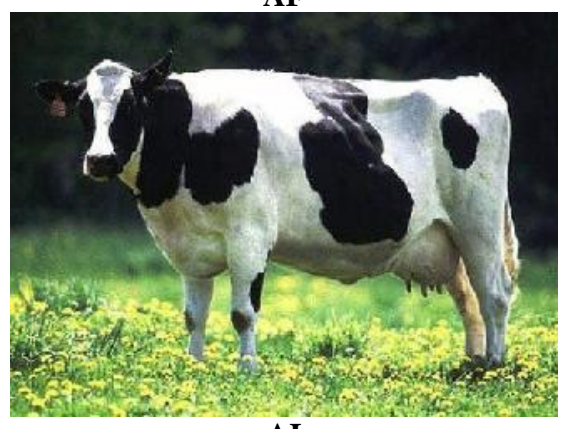

AI

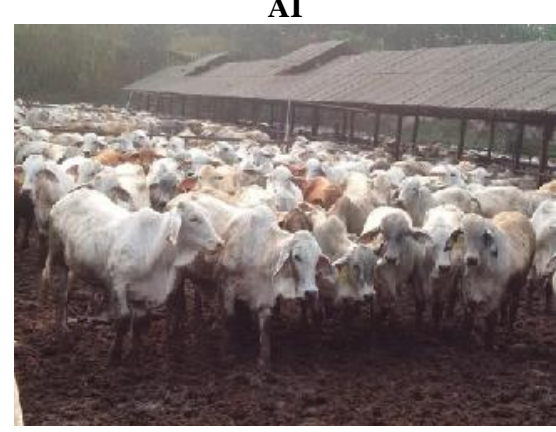

AL

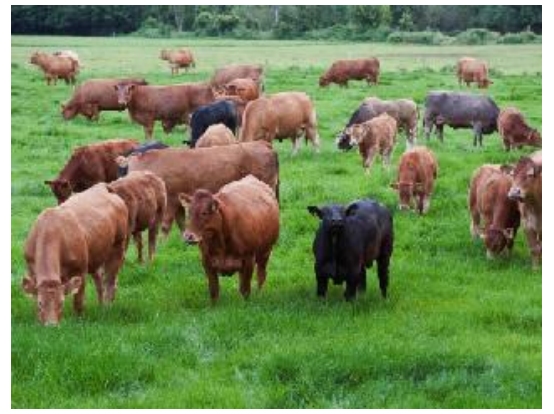

AG
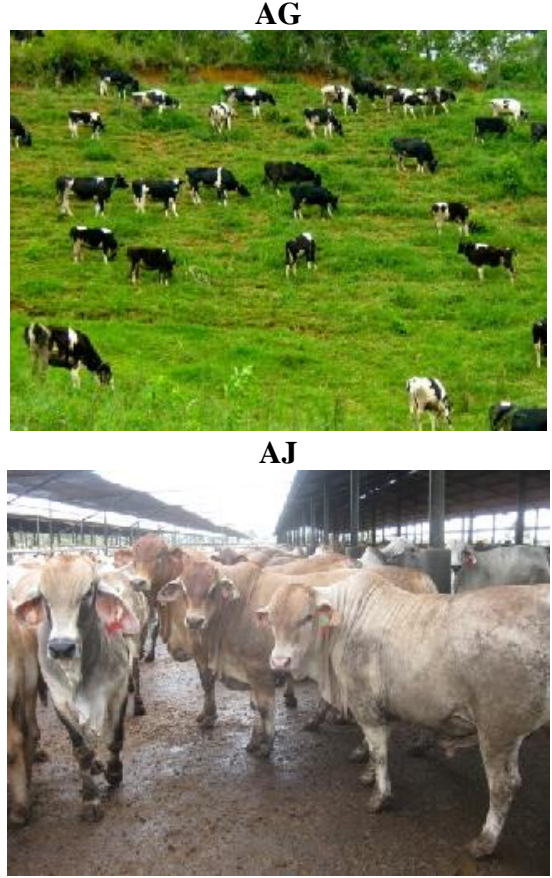

AM

Figure 1.The diversity of cattle in Indonesia. A-C. Banteng (males, females, herds); D-F. Bali cattle (bulls, cows, herds); G-I. Peranakan Ongole cattle (bulls, cows, herds); J-L. Madura cattle (bulls, cows, herds); M-O. Aceh cattle (bulls, cows, herds); P-R. Pesisir cattle (male, puppies, herds); S. Jabres cattle; T. Rancah cattle; U. Rambon-Bali cattle; V. Rambon-Madura cattle; W. Galekan cattle; X. Brahman Cross cattle; Y-AA. Brahman cattle (male, female, herds); AB-AD. Simmental cattle (bulls, cows, herds); AE-AG. Limousine cattle (bulls, cows, herds); AH-AJ. Holstein Friesian cattle (bulls, cows, herds); AK-AM. The appearance of various types of cattle at the feedlot enterprise (feedlofter) originating from northern Australia

dry season and able to be immediately restored to its original state if there is enough fodder; it can be kept as draught animals or beef cattle. Carcass percentage is higher than zebu and taurine cattle, with high-quality of low-fat beef. The quality of skin is good and rather thin. Bali cattle is the most suitable for farming in the traditional production system with low-input and high environmental stress which is widely practiced by Indonesian breeders (Wirdahayati 1994; Copland 1996; Diwyanto and Praharani 2010; Sutarno 2010; Zulkharnaim et al. 2010 ; Noor et al. 2011). Bali cattle have various disadvantages, namely slow growth, low milk production that lead to the high calf mortality (Susilorini 2010). These cattle are known as resistant to many diseases and parasites, but there are two very deadly diseases, namely malignant catarrhal that attack calves, and jembrana viral disease that attacks the brain (Budiarso and Hardjosworo 1976). Malignant catarrhal is detected in Denpasar, Banyuwangi, Mataram and Kendari (Damayanti 1995). First, jembrana viral disease infected the population on the island of Bali, and is allegedly as a result of long-term isolation that causes a lot of inbreeding and produce low resilient offspring (Tenaya 2010; Wilcox et al. 1992, 1995). It is quite alarming, as in some other places, Bali cattle has lower genetic variability than the one in Bali, for example, on the island of Lombok (Winaya et al. 2009). Jembrana viral disease has also been detected in Bali cattle population in West Sumatra, Jambi, Riau and Riau Islands. Previously, the disease has been successfully handled in Bali, East Java and Lampung (BPPV Bukittinggi 2013).

Breeding and conservation. Bali cattle have not experienced an advanced selection as zebu and taurine cattle have. However, the genetic purity of Bali cattle is now threatened by negative selection and crossbreeding. 


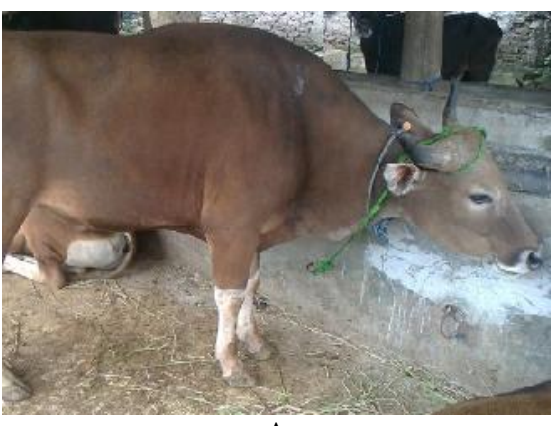

A

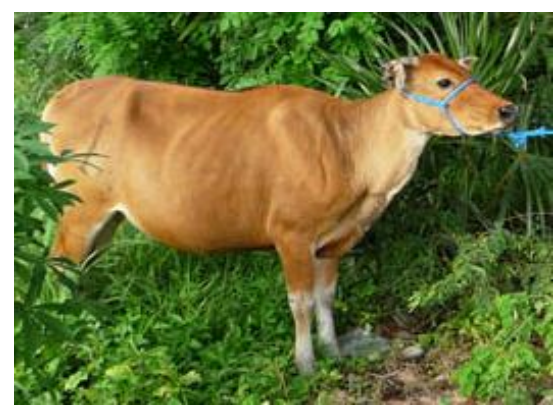

B

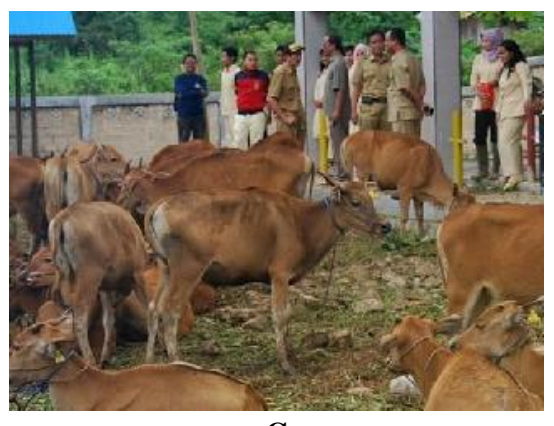

C

Figure 2. The quality depletion of Bali cattle from Kupang due to negative selection of poor quality cows mating. A. The bulls; B. The cows; C. Cattle herds.

Negative selection on the Timor island by shipping of highquality cattle and let the low quality ones to breed, causing the cattle's weight become progressively low (Wirdahayati 2010; Sudarma 2013)(Figure 2). The crossbreeding begins to be done even on the island of Bali, especially with frozen semen of Simmental and Limousin cattle. In the era of Klungkung kingdom to the colonial period, the island was set specifically for the development of Bali cattle. But today, specific areas for Bali cattle development is only on a small island of Nusa Penida (DGLSAH 2015), while in Bali Island, crossbreeding of Bali cattle with other cattle breeds has been allowed. However, there is a Bali Governor Regulation No. 45/2004 and Regional Regulation of Bali Province No. 2/2003 which prohibits shipping female breeds of Bali cattle out of Bali province. Genetic purity of banteng as a source domestication of Bali cattle is also threatened by interbreeding. Utilization zone of national parks in Baluran, Alas Purwo and Meru Betiri which are natural habitat for banteng, are used by local residents as domestic cattle grazing, particularly in $\mathrm{TN}$ Baluran (Tempo 27.6.2013), so there is possibility of wild banteng mating to domestic cattle and disturbing the genetic purity. The Indonesian government has made a banteng conservation action plan (Regulation of the Minister of Forestry No. P.58/Menhut-II/2011), but the results have not been much of an effect. In addition to the island of Nusa Penida, Bali cattle breeding are also concentrated in Siak, Central Lombok, Barito Kuala, Barru and West Pasaman districts (DGLSAH 2015).

\section{Peranakan Ongole and Sumba Ongole cattle}

Origin and distribution. Zebu cattle of Indonesia has been known for centuries as Java cattle, but the quality is steadily declining due to lack of new genes input, so at the early of the 19th century, it was brought here different breeds of the Indian zebu cattle for genetic improvement and it gave satisfactory results. In the early of the 20th century, the government took the initiative to bring Ongole cattle to Sumba Island and were able to breed and adapt well, they were known as Sumba Ongole cattle (Hardjosubroto 2004). Peranakan Ongole (PO) (Bos indicus) or Benggala is a crossbreed of uncontrolled mating of Java cattle and Sumba Ongole cattle (Suyadi et al.
2014). PO cattle population is estimated at about 2,9 million and almost 90\% is in Java (DGLS 2003,2010b).

Physical characteristics. PO cattle has a white or gray colored skin, fan tail and fur around the eyes is black, short curved shape of the head, short horns, long hanging ears, and a rather large belly. On male cattle, sometimes, there is black splotches on the knees, big bright eyes encircled with black spot about $1 \mathrm{~cm}$ from the eye; big body, big hump, short neck, long legs, strong muscle, wattle loose, hanging from the bottom of the head, neck to stomach. Male cattle can reach a weight of about $600 \mathrm{~kg}$ and female cattle are $450 \mathrm{~kg}$. PO cattle weight gain range between $0.4-0.8 \mathrm{~kg}$ per day, but in unfavorable conditions only reached $0.25 \mathrm{~kg}$ per day (Wiyatna et al. 2012). Meanwhile, SO cattle had reached the body weight gain of $1.18 \mathrm{~kg}$ per day, the percentage of carcass is more than $50 \%$ and meat production had reached 77\% (Ngadiyono 1995).

Advantages and disadvantages. PO cattle are known as beef cattle and draught cattle. They are suitable as draught animals due to a big and strong body, docile and quiet, tolerant to heat, have high adaptability over different environmental conditions, able to grow in limited forage conditions, and high reproductive activity. The female quickly returned to normal condition after giving birth. However, the percentage of carcass is generally lower than other Indonesian local cattle.

Breeding and conservation. In addition to PO cattle and SO cattle, in Indonesia it is also developed other species of zebu cattle, particularly breeds of Brahman and Brahman Cross, which is bigger than the PO. Pure PO cattle began rare because many breeders cross them with Brahman cattle. Their mating produces fertile calf and usually is also called PO because of its smaller size. In Kebumen, Central Java, PO cattle are also known as Madras cattle which are the origin of zebu cattle in East India. In Kebumen, zebu cattle genetic improvement efforts have been done long before Ongolisation program in 1930s, therefore the PO cattle (Madras) in this region are known to have qualities like pure Ongole cattle (Utomo et al. 2015). Kebumen, Gunungkidul and South Lampung have been chosen as the breeding center of PO cattle (DGLSAH 2015). 


\section{Madura cattle}

Origin and distribution. Madura cattle (Bos javanicus $x$ Bos indicus) are the result of a crossbreed between Bali cattle and zebu cattle from India in the island of Madura, but the time is unknown. Some sources say that the process occurs about 1,500 years ago (Meijer 1962; NRC 1983; Nijman et al. 2003). Given the Madura cattle also dominant on the northern coastal region of East Java where there are many Madurese immigrants, then certainly these cattle were already present before the migration. The area is experiencing depopulation of Javanese because of war continuing from the 15th to 18 th centuries. The Madurese fill these abandoned lands because the previous owners are victims of war or escape. At the beginning of the 20th century, Madura cattle are distributed to Flores and East Kalimantan. But, they are replaced by Bali cattle which are brought in later for the better quality (Omerling 1957; Hardjosubroto 2004). In 2002, the total population of Madura cattle is approximately 900,000 (DGLS 2003). In 2008 on the island of Madura, the population is approximately 400,000 (Office of Animal Husbandry East Java Province 2009), and in 2010, it is about 635,000(DGLS 2010b).

Physical characteristics. Madura cattle is brick red or brownish red with distinctive white markings on the back and below. It has small horns, short and heading outside. The uniformity of breeding is developed through selection conducted by the breeders.

Advantages and disadvantages. Madura cattle has good growth in poor quality of forage, the percentage of carcasses is high with meat quality is good; it has high adaptability to tropical environments, and can run fast, so it is usually used for racing (karapan), and have a good body appearance, so it is also used as displayed cattle (sonok). Karapan cattle require high energy metabolism to get physical strength, hard work of skeletal muscle, and the aggressiveness. On the other hand, sonok cattle need to withstand muscle framework stretching and emotions (tamed). Cattle that do not have these properties are categorized as common beef cattle. Madura cattle breeders keep them as draught animals, life savings, producer of organic fertilizer, source of revenue and for the karapan and sonok cattle (Siswijono et al. 2010). Compared to Bali cattle, Madura cattle are relatively resistant to jembrana viral diseases (Suwitri et al. 2008).

Breeding and conservation. Karapan race and sonok festival are instrument of Madura cattle selection, which can only be attended by the selected cattle with excellent performance and condition. It can be affected by genetic and environmental factors, including feed and health. The selection of cattle having performance appropriate to the tastes of society needs to be considered, if it affects variations in genes involved in energy metabolism or not (Siswijono et al. 2010; Febriana et al. 2015). In the colonial era, Madura Island is specialized for Madura cattle development and the introduction of other cattle breeds is prohibited. This was stated in Staatsblad (Gazetted) No. 226/1923, No. 57/1934, and No. 115/1937. Even it implied in Indonesian Law No. 18/2009, on Animal Husbandry and Animal Health. However, development of other cattle is allowed in the later. In 1957, the crossbreeds of Madura cattle with dairy cattle Red Danish (a taurine cattle) was carried out, but the calves are less than desirable, and in recent decades Madura cattle are crossed with Limousin through artificial insemination with the results of considerable interest, because have larger body size and higher selling price (Siswijono et al. 2010). The crossbreeds of Madura and Limousin cattle are the belle for traditional breeders. This process is carried out directly in the field and is not controlled exclusively, so that in the long term, there is a concern that it will change the genetic composition of Madura cattle and affect the durability of the dry climate and limited fodder. Furthermore, it can disturb the continuing of local culture of karapan and sonok cattle (Widi et al. 2013) as well as reduce the ability of self-sufficiency in beef cattle. Sapudi Island is pointed as pure Madura cattle conservation area in order to avoid the uncontrolled genetic changes (Decree of the East Java Governor No. 188/Kpts/013/2010; DGLSAH 2015). However, in this island are also reared PO cattle and its breed (Kutsiyah 2012).

\section{Aceh cattle}

Origin and distribution. Aceh cattle (Bos indicus) are a small-sized local cattle developed in Aceh (Martojo 2003; Dahlanuddin et al. 2003). Aceh cattle allegedly were imported by Indian merchants in the past (Abdullah et al. 2007).

Physical characteristics. Aceh cattle are predominantly red-brownish for male and red brick for female; the color around the eyes, the inner ear and upper lip is whitish, neck is darker in males; it has a dorsal blackish brownish stripe, red brick hamstrings, light brownish buttocks, whitish legs, black tail tip, generally concave face, generally concave back, horn leads to the side and curved upwards, small ears leading to the side and do not droop. Body weight is $253 \pm$ $65 \mathrm{~kg}$ of male, $148 \pm 37 \mathrm{~kg}$ of female. Carcass percentage is $49-51 \%$. Aceh cattle have good adaptability, employability and disease resistance. They are very productive, with the parent fertility of $86-90 \%$, birth rate of 65-85\%, age of puberty of 300-390 days, estrus cycle of 18-20 days and 275-282 days old pregnancy (Abdullah et al. 2007).

Advantages and disadvantages. Aceh cattle are used as beef cattle and draught animals. Most local farmers utilize Aceh cattle to plow the field. Aceh cattle breeding business is generally done by individuals, there has been no industrial-scale livestock enterprises (Abdullah et al. 2007; 2008). Although relatively small in size, some Aceh cattle have the ability to give birth to twin calf.

Breeding and conservation. In Indrapuri, Aceh, there is a special institution that develops Aceh cattle breeding. Raya Island of Aceh Jaya is designated as specific areas for the breeding and development of Aceh cattle (DGLSAH 2015).

\section{Pesisir cattle}

Origin and distribution. Pesisir cattle (Bos indicus) are local cattle breeds that have the smallest body size. These cattle are widely kept in Pesisir Selatan district, and 
on a small portion in the districts of Padang Pariaman and Agam, West Sumatra (Anwar 2004; Hosen 2006). Population of Pesisir cattle continues to decline. In Pesisir Selatan, it only reached 76,111 heads in 2011 (OAHAHP Pesisir Selatan District 2012). The decline of Pesisir cattle population is allegedly associated with high slaughtering of productive livestock, forage limitations, pasture depreciation, and decreased genetic quality (Adrial 2010).

Physical characteristics. Pesisir cattle have small bodies, short stature, slender legs, small hump, and benign. Male cattle has a short head, short and large neck, wide at the back of the neck, a big hump, short and round steering. Female cattle has a rather long head and a thin, sloping tail, short and thin, small horns and head for outside such as goat horns (Saladin 1983). Adult male cattle (age 4-6 years) has only a weight of $160 \mathrm{~kg}$ (Adrial 2010). The high diversity of skin color with a single pattern and is grouped into five dominant colors, namely red brick (34.3\%) yellow $(25.5 \%)$, chocolate $(20 \%)$, black $(10.9 \%)$, and white $(9.3 \%)$ (Anwar 2004).

Advantages and disadvantages. Pesisir cattle have a high reproductive efficiency (Sarbaini 2004), high birth rates, birth weight of $14-15 \mathrm{~kg}$, average daily weight gain from birth to calf about 0.32 to $0.42 \mathrm{~kg}$ per day (Saladin 1983). Carcass percentage is $50.6 \%$. They are able to survive in adverse environmental conditions and poor forage. The ability to convert fibrous feed into meat is high (Saladin 1983). Pesisir cattle traditionally are maintained by relying on pasture grass, vacant lots, and rain fed; are resistant to disease and able to adapt to a tropical environment (Hendri 2013). Improvement in forage quality can increase the growth rate and carcass percentage, although it will increase the percentage of fat (Khasrad and Ningrat 2010).

Breeding and conservation. Development of the Pesisir cattle is exposed to the genetic deterioration. Body weight and body size of these cattle are much smaller than before. For 22 years (1982-2004), the body weight and body size of Pesisir cattle have decreased around $35 \%$. For 25 years (1980-2005), body weight of adult male of Pesisir cattle have decreased from $275 \mathrm{~kg}$ to $237.5 \mathrm{~kg}$, while female cattle have decreased from 256 to $172 \mathrm{~kg}$ (Sulin 2008). Today, breeders prefer exotic cattle such as Brahman and Simmental, as well as Bali cattle, especially since the government introduces thousands of Bali cattle to West Sumatra since 1985 (Wilcox et al. 1996; Mariani 2013) and introduce artificial insemination later. In 2009, Pesisir cattle population is still dominant, reaching $70 \%$ of cattle population, but in 2011 it is only 25\% (Hendri 2013). Since there are no Pesisir cattle conservation efforts, in the long term, these breeds will be allegedly replaced by Bali cattle which are more superior. Pasaman Barat, one of the original distributions of Pesisir cattle, was chosen to be the center of Bali cattle breeding (DGLSAH 2015). However, in Padang Mengatas, District of Limapuluhkota, there are breeding of various cattle breeds, including Pesisir cattle.

\section{Jabres cattle}

Origin and distribution. Jabres cattle (Bos javanicus $x$ Bos indicus) (Jabres = Java Brebes) are allegedly to be a crossbreed between Madura cattle or Bali cattle with Peranakan Ongole cattle (Minister of Agriculture Decree No. 2842/Kpts/LB.430/8/2012). This cattle thrive in the highlands of southern Brebes, Central Java at an altitude $800 \mathrm{~m}$ asl. (Lestari 2012). According to Munadi (2010), Jabres cattle are found in five sub-districts, namely Bantarkawung ( 5,757 heads), Salem ( 543 heads), Banjarharjo ( 1,994 heads), Ketanggungan ( 2,900 heads), and Larangan ( $\sim 890$ heads).

Physical characteristics. Jabres cattle have similar characteristics to Bali cattle, but Bali cattle has a white color on the legs and buttocks that contrasts with the body color of red-brownish, on the Jabres cattle, that color becomes gradation and has no visible boundary between red-brownish and white. The color varies from brownish, white brownish, white, dark-brownish and black; white feet, white upper lip, white lower lip; in the head, it is often found signs of a small white rhombus, black tip. The cattle have rump, white hind legs, and the black stripe from the back to the tail. Male cattle horns curved upward, the female curved downward. In general, there is no hump. Body shape is slim and compact with dense flesh structure. Male cattle body weight is $350 \pm 25 \mathrm{~kg}$, female cattle is $286 \pm 20 \mathrm{~kg}$. Fertility of parent is $82-85 \%$, with $40-85 \%$ of birth rate and estrus cycles of 18-24 days, pregnancy period of 9-10 months, 21-28 months of the first estrus, first birth age of 30-36 months (Decree of the Minister of Agriculture No. 2842/Kpts/LB.430/8/2012; Lestari 2012).

Advantages and disadvantages. Jabres cattle have the ability to work and high adaptability to extreme climate conditions, are able to utilize lower quality feed, not susceptible to disease, insect-resistant, and have good reproducibility. One female of Jabres cattle able to give birth up to 15-20 times; with calving interval is only 12 months. It can be pregnant by 45 days after birth. The average birth weight is $16 \mathrm{~kg}$ to facilitate calving, whereas the weight of adult males ranged between 195-269 $\mathrm{kg}$ and females 168-296 kg. Cattle meat has a solid structure; carcass percentage can reach 52\% (Lestari 2012).

Breeding and conservation. Jabres cattle traditionally are maintained with fellow cattle grazing systems (Adiwinarti et al. 2011; Lestari 2012). Mating system of Jabres cattle occur naturally. Breeding through artificial insemination with exotic cattle have not done for reasons of cost, so that the genetic purity is relatively maintained. Jabres cattle are the only local cattle of Central Java, and are chosen as a local cattle based on the Decree of the Ministry of Agriculture No. 2842/Kpts/LB.430/8/2012.

\section{Rambon cattle}

Origin and distribution. Rambon cattle (Bos javanicus $x$ Bos indicus) are local cattle in the eastern part of East Java, especially in Bondowoso, Situbondo, Jember and Banyuwangi. In the past, there were three cattle breeds in this area, namely PO cattle, Madura cattle and Bali cattle. Rambon cattle are natural crossbreeding of the three breeds so that their genetic composition is quite diverse (Susilawati et al. 2002; Susilawati 2004). Rambon cattle living in Situbondo and Bondowoso have characteristics which are predominant to Madura cattle and PO, while 
Rambon cattle in Jember and Banyuwangi have characteristics which are predominant to Bali cattle and PO (Susilawati et al. 2002; Susilawati 2004). It is strongly associated with the geopolitical history of the region in the past. Until the 18th century, there was still existing Hindu kingdom of Blambangan in Banyuwangi which periodically obtains the influence of Bali (Margana 2007). The Balinese allegedly bring in Bali cattle from Bali island, but the other opinion says that Bali cattle were domesticated in this region since, until now, there is still a wild banteng, such as in Baluran National Park, Alas Purwo National Park and Meru Betiri National Park. In the 18th century, the region fell to the kingdom of Mataram and Madurese began migrating mainly on the north coast, bringing Madura cattle with them. Bali cattle are dominant in the south and Madura cattle dominate the north area. Consequently, the breeds of Rambon cattle in the north tend to resemble Madura cattle, while the cattle in the southern part resemble to Bali cattle. According to Amin (2010), Rambon cattle of Banyuwangi experienced natural crossbreeding with Bali cattle, PO cattle and Brahman, and underwent cross through artificial insemination with Limousin, Simmental, Aberdeen Angus and Santa Gertrudis cattle.

Physical characteristics. Rambon cattle have a weight of about 300-400 kg. Rambon cattle in Situbondo and Bondowoso has a dominant varied skin color; brick red, red-brownish, red without clear color boundary; white rump; long tail with black fur; diverse foot fur, clear white, white, red brick; diverse shape of backs, straight or curved, with or without the back line; varies direction of the horn, forwards, upwards, sideways and backwards; the existence of hump varied, with hump, no hump and unclear hump. On the other hand, Rambon cattle in Banyuwangi and Jember are predominantly of red brick; thin wattle; black back line; white leg fur; specific white rump; the horn direction is to the side; tail with black fur; no hump (Susilawati et al. 2002; Susilawati 2004).

Advantages and disadvantages. Rambon cattle are composite that have high resistance to climate, feed and disease in the eastern of East Java. However, as the descendants of Bali cattle, these cattle are not resistant to jembrana viral diseases, so the local government has banned the cattle-shipping from Bali to East Java (Circular of East Java Governor No. 524/8838/023/2010).

Breeding and conservation. Rambon cattle are a natural crossbreeding and need no efforts for conservation. Rambon cattle experience a lot of genetic mixing, including artificial insemination with Simmental and Limousin as the main stud, so there are dozens breeds of these cattle (Amin 2010).

\section{Rancah cattle}

Origin and distribution. Rancah cattle or Pasundan cattle (Bos javanicus $x$ Bos indicus) are local cattle in West Java. The naming is based on the location of initial development, namely Rancah, Ciamis, West Java. These cattle are often called kacang (bean) cattle because it is relative small in size (Hilmia et al. 2013). Distribution area includes Ciamis, Tasikmalaya, Pangandaran, Garut,
Cianjur, Sukabumi, Purwakarta, Majalengka and Kuningan (Indrijani et al. 2012).

Physical characteristics. Rancah cattle have physical characteristics as Madura cattle and Bali cattle. The females have no hump; body size is relatively small, mostly red brick and white on the pelvis and on the four lower legs (tarsus and carpus) with no clear restrictions. There is a stripe along the back with the older color of the dominant colors. Male cattle are similar to females, but mostly with darker body color. Some Rancah cattle male may experience changes in color from brick red to black according to sexual maturity (such as Bali cattle). Rectangular shape with long small legs and has a short horn but not uniform and varies from small to large. Body size is with an average shoulder height of $115 \mathrm{~cm}$ to 109 $\mathrm{cm}$ in males and females. Male cattle body weight on average $240 \mathrm{~kg}$ and $220 \mathrm{~kg}$ in females (Payne and Rollinson 1973; Huitema 1986; Decree of the Minister of Agriculture No. 1051/Kpts/SR.120/10/2014). In Rancah, Ciamis, these cattle are relatively small compared to other breeds which are also kept by cattle breeders, such as PO, Simpo and Limpo (Derajat 2014).

Advantages and disadvantages. Their behavior is not wild and easy to adapt to the surrounding environment. Reproductive ability is quite efficient; it can be re pregnant within 2.5-5 months after birth (Hilmia et al. 2013). They have superior carcass percentage reaching $50 \%$ of the live weight, the fat content in meat is low, the meat is more abrasive, does not contain a lot of water; the meat color is brighter because of the high pigment content, so the price is more expensive than imported beef cattle. In addition, these cattle have high resistant to tropical diseases; practicality in taking care of; resistant to extreme weather. Rancah cattle growth is relatively slow, although it can live with a low quality feed, but the fostering costs are much cheaper, about $25-30 \%$ of crossbreed cattle.

Breeding and conservation. Pure Rancah cattle populations have decreased, there were only about 3001000 heads, their existence is marginalized by other cattle. By 2015, at Rancah Animal Market, 70 cattle are sold every day, but only $30 \%$ which is a Rancah cattle or its crossbreed. The decreasing of Rancah cattle population leads to an increase of inbreeding so that it lowers the quality of these cattle. In 1990, one of Rancah cattle could produce $500-700 \mathrm{~kg}$ of carcass, but at present, it is only able to produce $300-350 \mathrm{~kg}$ of meat carcasses. Genetic improvement efforts to restore the quality of Rancah cattle as in the past are relatively difficult, because of the difficulty in finding good (pure) quality Rancah cattle. In addition, these efforts require a long time commitment (about 25 years), high cost and there is no serious institution that handles Rancah cattle breeding, all produced naturally to breeders. This genetic decline is responded by breeders by crossing it with other local cattle, especially PO cattle. In 2014, there were 52,540 heads of Rancah cattle, but it is mostly the result of crossbreeding with other local cattle. Artificial insemination is also conducted intensively in this region, causing introgression from other cattle gene (Hilmia et al. 2013). Genetic improvement can be done by inserting the wild banteng 
gene back to Rancah cattle. These species still found in West Java, namely in Leuweng Sancang forest, Garut. The mating is expected to restore the performance of Rancah cattle as the original which is more robust and meaty. In addition, certain areas need to be protected since it is the source of Rancah cattle breeds, mostly scattered in the forest area in the district of Ciamis, Pangandaran, Garut and Cianjur. The protection can be done by, for example, banning Rancah cattle interbreed with other breeds of cattle. It should also be supported by breeding policies so that the quality of cattle is maintained well, such as sperm banks and embryo transfer. Rancah cattle have been classified as newest Indonesian local cattle based on Decree of the Minister of Agriculture No. 1051/Kpts/SR.120/10/2014.

\section{Galekan cattle}

Origin and distribution. Galekan cattle (Bos javanicus $x$ Bos indicus) are one of the cattle germplasm which needs to be conserved due to a sharp population decline. This cattle breed is allegedly as a crossbreed of Java(PO) cattle and Bali cattle.

Physical characteristics. Skin color is light brownish, dark brownish to blackish red brick, and while white or light brownish on the buttocks and the edge of wattles with an undefined border, lower legs are white with defined borders. Tail is long with black hair; has a dark eye circles and straight back striped with black dorsal stripe. These cattle are humped and horned with black striped ears and long little horn which initially came out sideways, then out onto the front. Habitat is in dry lowland usually grazing in the seashore, 66-322 $\mathrm{kg}$ body weight; performance is 3-5 months of anoestrus post partus; services per conception are 1.3 times and calving interval is 14-18 months (Aryogi and Romjali 2009).

Advantages and disadvantages. Galekan cattle have a larger body size than most of the local cattle, thus it becomes popular beef cattle that it is to threaten its sustainability.

Breeding and conservation. Galekan cattle are local cattle from Trenggalek, East Java. Galekan cattle belong to type of superior cattle, but its presence is very critical because of being pressured by the development of PO cattle breeding and from new species of cattle that comes out from artificial insemination. The continuous natural processes of crossbreeding with PO cattle cause genetic purity to be blurred and difficulty to identify the descendants as Galekan cattle breeds. At this time, the number of pure Galekan cattle is in estimation of 20-500 heads. These cattle have distribution in coastal area of Trenggalek district, East Java (Aryogi and Romjali 2009).

\section{Grati cattle (FH Indonesia)}

Origin and distribution. Grati cattle (Bos taurus $x$ Bos indicus) are the only local dairy cattle that are still raised by breeders. At the beginning of the 20th century, various taurine dairy cattle were imported into Grati, Pasuruan and were mated with local cattle, to get dairy cattle that are resistant to tropical climate (Sudono et al. 2003; Siregar 1995; Soehadji 2009). But from the physical appearance,
Grati cattle are the result of a mating of males FH cattle with PO females. These cattle have gained international recognition as local dairy cattle of Indonesia (Payne 1970). These cattle were once widely kept in highland of Pasuruan and Malang (Pujon, Nongkojajar, Batu and surroundings) (AAK 1995), but the quality is declining and a back crossbreed of a pure FH male cattle with PO females needs to be done. Grati cattle are now known by the name of FH Indonesia (FHI). Unlike its predecessor whom quality is steadily declining and is abandoned by many breeders, FHI cattle are still being developed and the semen is widely used for artificial insemination program (BBIBS 2015). The population of old Grati cattle had reached less than 10,000, while the number of new Grati cattle (FHI) has not been recorded (Sariubang1992; DGLS 2003).

Physical characteristics. Grati cattle has a color similar to the FH cattle, namely striped black and white skin, but not as bright as FH, on the forehead are white triangles and on the chest, lower abdomen, tail and legs are white; wide long and straight head, small and short horns heading to the front; body size and milk production is lower than FH.

Advantages and disadvantages. At first, Grati dairy cattle were able to produce milk with average of 15 liters per day, but since there is no further genetic improvement, milk production capacity has decreased to only 12.3 liters per day with lactation period of 9 months. These cattle are able to adapt to the hot tropical environments, and are easily controlled, docile and quiet. With intensive feeding, weight can increase to $0.9 \mathrm{~kg}$ per day (Syarif and Harianto 2011). Grati cattle on the plateau show better yields than the one in the lowlands (Ratnawati et al. 2008).

Breeding and conservation. Grati cattle will experience a loss of quality, especially milk production, in line with the increasing generation, so FH male cattle is always needed to maintain the quality.

\section{EXSOTIC LIVESTOKS}

In 1970-1980, various zebu and taurine cattle breeds live or their frozen semen were introduced from Europe, USA, Australia and New Zealand and crossed with the local cattle. Zebu cattle breeds imported mainly Brahman and Brahman Cross, while the breeds of taurine cattle imported mainly Simmental, Limousin, Holstein Friesian, and the Australian Commercial Cross (ACC). The imported cattle have very high daily body weight gain, but it is not suitable to be maintained in hot tropical regions, except for Brahman and Brahman Cross. In Indonesia, there are also several other exotic cattle, but not much developed. Since the 1990s, the production of beef cattle in the country is insufficient and each year continues to increase imports of beef cattle, mainly from Australia and the United States. In the end, imported feeder cattle to be fattened mainly Brahman Cross and the Australian Commercial Cross breeds of Australia. By 2015, as many as 650,000 head of Australian cattle entry in Indonesian feedlofter, unfortunately these cattle lasted only 3-6 months in fattening and slaughter, not bred. Today, often found 
crossbreeds between taurine cattle breeds of Simmental and Limousin with local cattle, especially with Peranakan Ongole, through artificial insemination (Pamungkas et al. 2012). However, this breeds has not been naturalized well where pregnancy process almost through artificial insemination, produce offspring of male sterile and fertile females, but steadily declining reproduction from generation to generation. In the long term, this concern will change the genetic composition of local cattle Indonesia (Putro 2009).

\section{Friesian Holstein}

Friesian Holstein (FH) or Holstein Friesian (Bos taurus) have been developed since the 13th century in the Netherlands (North Holland and Friesland) and Germany (Schleswig-Holstein). A century after the breeding effort produced the best dairy cattle in the world in typical black and white colors, this color is preferred than the original brownish color that is also found in this breeds. In Indonesia, the first $\mathrm{FH}$ cattle imported from the Netherlands in the 19th century, the next imported cattle came from Australia, New Zealand, USA, Japan and Canada. These cattle have a good performance in producing milk and meat, and have good reproducibility. These cattle are generally maintained in the highlands of Java, at an altitude of $700 \mathrm{~m}$ asl., but its crossbreeds with PO can live at an altitude of $300 \mathrm{~m}$ asl. In 2002, the population of $\mathrm{FH}$ cattle in Indonesia was approximately 354,000 heads (DGLS2003) and now about 500,000 heads (DGLSAH 2014). This stock is generally a relatively pure Holstein Friesian breeds, because in descendant of $\mathrm{FH}$ cattle, the production of milk and beef are far less than of pure breeds. However, there is still an offer of FH cattle descendant as the result of crossbreeding between FH cattle males and PO cattle females. These cattle was formerly known as Grati cattle, but is now named Indonesian FH cattle. These breeds have high genetic quality i.e. high milk production (about 20 liters per day) and have high adaptability to tropical environment, birth weight average of $35 \mathrm{~kg}$ and have a rapid growth, giving birth ability at the age of around 25 months, with a calving interval of about 12.6 months. Pure FH cattle are generally black and white patterns, sometimes red with white streaks and clear color boundaries. The head is long, wide, and straight, with relatively short horns and curved toward the front (Sudono et al. 2003; Siregar 1995); Mouth of FH cattle is wide, nostrils are wide open, powerful jaws, bright eyes, medium ears, wide forehead, long and thin neck; the location of the shoulder is a good deal on the chest wall and forming relationships neatly with the body, strong back and flat with vertebrae associated in good way, long and wide steering, rectangle, short nails with a good circle, low heels with flat palms, big udder and hanging down at the back of belly between the thighs (Samad and Soeradji 1990).

\section{Simmental}

Simmental cattle (Bos taurus) are originated from Simme valley, Switzerland. These cattle have been developed since the 13th century, and became the female broodstock for various newer breeds of cattle. In 1985,
Indonesia got live cattle and frozen semen of Simmental from Australia and New Zealand. Simmental cattle are subtropical cattle. In Indonesia, the pure breeds are only being kept in government-owned research or large breeder located in the highlands to take the semen. Stocky and muscular body shape, a very good muscle development; high carcass yield with less fat, adult's body weight can reach over $1,000 \mathrm{~kg}$. Simmental cattle of the United States are black due to selection, but the breeds developed in Indonesia is yellow-brownish or red face, knees down and the tail tip are white as the original characteristics of this breeds. In Indonesia, it is only used as beef cattle and many crossed with the local cattle through artificial insemination, especially with Peranakan Ongole cattle, but also Madura cattle, Bali cattle, and even FH cattle. The result of crossbreeds male is preferred because it grows faster, while female calf less satisfactory growth and yield little milk. At the age of 2.5 years the weight has reached $1,000 \mathrm{~kg}$. Artificial insemination performed directly in the field and produce offspring with untested ability to adapt to the climate, feed and local diseases. But breeders like this business because young cattle are having a larger size and faster growth than the local cattle, and it continues. In the long term this needs attention due to genetic changes in local cattle of Indonesia.

\section{Limousin}

Limousin cattle (Bos taurus) that originated from Limousine and Marche, France have been developed since the 17th century. These cattle have a long, large, compact body, as well as a large chest, shallow ribs, thick and fleshy, with a pattern of meat better than Simmental. Its eyes are sharp; well-built legs. In males, the horns grow out and slightly curved. Its skin is dark red, brownish, or yellow rather gray, but white around the udder and the knee down and the color around the eyes are lighter. At this time, it has been developed Limousin cattle without horns and black. Male cattle weights can reach $1400 \mathrm{~kg}$, while females $850 \mathrm{~kg}$. The productive period of female cattle is between 10-12 years old. They are the most rapid cattle in weight gain, i.e. $1.1 \mathrm{~kg}$ per day. Because they come from the sub-tropical climate, they are only suitable to be maintained in the highlands that have a high rainfall. These cattle are resistant to attacks of various diseases. Worldwide, the cattle are widely used for crossbreeding with various other breeds of cattle. In Indonesia, the cattle semen is used for insemination in local cattle, especially PO cattle, even with Brahman cattle.

\section{Brahman and Brahman Cross (BC)}

Brahman Cross cattle (Bos indicus x Bos taurus) are the result of crossbreeds between zebu cattle of Brahman breeds with some taurine cattle breeds in Australia. Brahman breeds were first developed in the United States since 1849 and became genetic sources for some new breeds. Brahman cattle have a large body, long and deep, humped over the shoulders; and the loose-skinned, wattle bark from the lower jaw to the tip of the front chest with many folds. Elongated head, large ears and a pointed-toe hang. It has big thighs, thick and loose skin. The skin color 
is varied, generally white and gray, but there are also black, brownish, red, yellow, and striped. These cattle are the best pieces to be developed in the lowlands because it is resistant to high heat and parasites (Banerjee 1978; Gunawan 2008). Brahman Cross cattle come from crossbreeds between Brahman cattle and various taurine cattle in Australia since 1933, so that the genetic mixture in every offspring varies widely (Banerjee 1978; Turner 1977; Friend and Bishop 1978). This cattle have good growth (1.0 to $1.8 \mathrm{~kg}$ per day), high carcass yield (45-55\%), resistant to tropical climates, and resistant to various diseases, mites or ticks. In 1973, the Brahman Cross cattle being imported into Sulawesi, Indonesia (Gunawan 2008) to be used as a draught cattle and cut in old age. In 2006, they massively distributed throughout Indonesia to support the acceleration of self-sufficiency in beef cattle program. Artificial insemination with semen of Brahman or Brahman Cross with PO cattle is preferred because it produces fastgrowing livestock and able to adapt to local conditions. Today in Indonesia, especially in West Java, Banten and Lampung many emerging fattening companies (feedlofters) are intensively fatten Brahman Cross breeds. Maintenance is ideal for fattening cattle for 60-70 days for females, and for 80-90 days for male cattle.

\section{Australian Commercial Cross (ACC)}

Australian Commercial Cross (ACC) cattle (Bos indicus $x$ Bos taurus) have unclear genetic origins, they are from open crossbreed between various cattle in pastures which are raised in Northern Australia and Queensland. In the pasture, Brahman, Shorthorn and Hereford cattle are raised (Beattie 1990). Thus, allegedly ACC is a cross between zebu cattle of Brahman breeds with Shorthorn and Hereford taurine cattle (AMLC 1991; Ngadiyono 1995). However, in contrast with the Brahman Cross, these cattle have characteristics more like Hereford and Shorthorn, the body is shorter and dense, large head, small ears and do not hang up, do not have a hump and wattle, fur around the head, the color pattern varies between Hereford and Shorthorn cattle. These mixed genetic cattle is very promising for fattening program, because it is easy to adapt to suboptimal environments like Brahman breeds and has a rapid growth like Shorthorn and Hereford. If a small and young ACC cattle is fattened in a short time (60 days) it would be very beneficial because it produces daily weight gain $\pm 1.61 \mathrm{~kg}$ per day with a feed conversion 8:22 (Hafid 1998). Along with Brahman Cross, ACC cattle are excellent for large cattle fattening companies (feedlofters) in Indonesia.

Therefore, there are indigenous cattle, local cattle and exotic cattle in Indonesia. The only native cattle of Indonesia is Bali cattle. Local cattle of Indonesia is an exotic cattle that has long been nurtured in Indonesia and even mixed genetically with Bali cattle, namely Peranakan Ongole cattle, Sumba Ongole and Madura cattle, as well as Aceh cattle, Pesisir cattle, Jabres cattle, Rancah cattle, Rambon cattle, Galekan cattle, and Grati cattle (FHI). Several exotic cattle had been introduced to Indonesia, but the main cattle include Brahman, Brahman Cross, Simmental, Limousin, Holstein Friesian, and ACC cattle.
Indonesian cattle distribution and density in each province is shown in Figure 3 and 4, respectively. The relationship between Indonesian local cattle with several major world breeds of zebu cattle shown in Figure 5.

\section{QUALITY IMPROVEMENT}

Development of cattle in Indonesia has been practiced for thousands of years and is still being done until now to improve the quality and quantity of cattle population. Livestock production is influenced by environmental and genetic factors. Environmental factors include feed, both forage and concentrate, water, climate, facilities maintenance, and is controlled by the gene (Sutarno 2006). Both can be manipulated, but genetics plays a larger role because it determines the level of reproduction, productivity of meat or milk, carcass percentage, growth rate, feed efficiency, resistance to climate and disease, physical strength as draught animals, etc. (Frankham et al. 2002). The main obstacles to the sustainable use of cattle are a lack of information about the population of local cattle, geographical distribution and genetic characteristics (Long 2008). Phenotype and genetic characterization in cattle population is still limited (Hannotte and Jianlin 2005). Almost all cattle in the world are descendants of two bovine species, namely zebu (humped) and taurine (without hump). The history of formation of both cattle from wild aurochs ancestors have been traced through mitochondrial DNA (mtDNA) (Baig et al. 2005). Bali cattle are the only other breeds of bovine significantly raised.

Cattle diversities are formed through mutations, genetic drift and artificial selection of species from wild ancestor (Long 2008). Genetic studies are necessary to prevent loss of quality cattle. One threat to the sustainability of livestock is inbreeding and loss of genetic variation. To ensure a population can multiply in a sustainable manner, the level of genetic variation in a population needs to be known. Genetic variation is often correlated with fitness; reduced genetic variability may limit the success of population to respond to environmental changes, such as climate change, disease or parasites (Frankel and Soule 1981). Inbreeding causes decreased genetic variation resulting in lower livestock resistance to environmental change and disease. Inbreeding generally occurs in small isolated populations without the input of new genes from the outside. Isolation of Bali cattle in Bali, by preventing the entry of new gene suspected to have caused decreased resistance to disease that jembrana viral disease can infect them (Tenaya 2010).

Growth is the most important indicator in the meat production of cattle, so it has important economic value in livestock raising (Sutarno 2006). The inserting of new genes through hybridization with other related cattle breeds may threaten the purity and the specific characteristics of one breed of livestock. In the colonial era, the island of Madura declared to be closed to other cattle breeds and only devoted to the development of Madura cattle; while Bali Island is devoted to the development of Bali cattle, even has started since the Klungkung kingdom. However, 


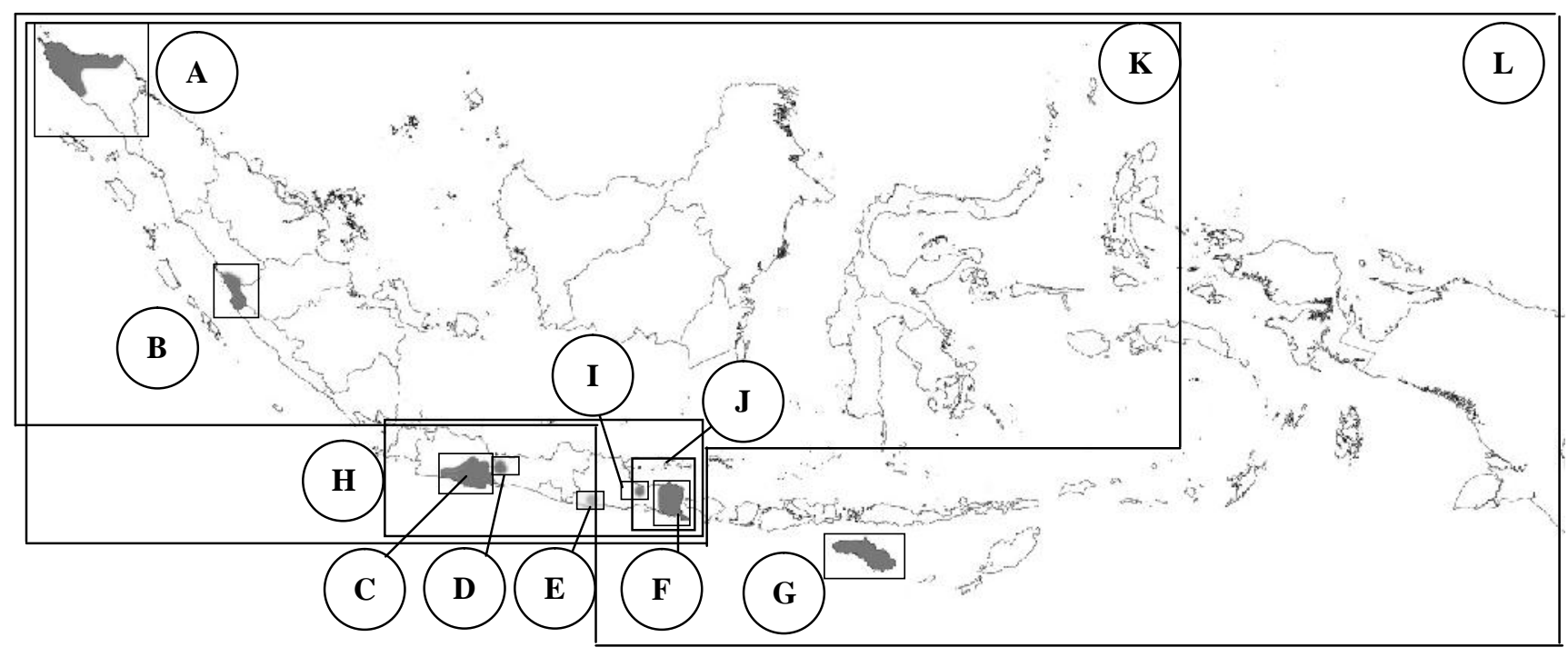

Figure 3.Distribution of local Indonesian cattle. A. Aceh cattle; B. Pesisir cattle; C. Rancah cattle; D. Jabres cattle; E. Galekan cattle; F. Rambon cattle; G. Sumba Ongole cattle; H. Holstein Friesian cattle; I. Grati cattle; J. Madura cattle; K. Peranakan Ongole cattle; L. Bali cattle (All Indonesia except for Central Java, West Java and Banten)

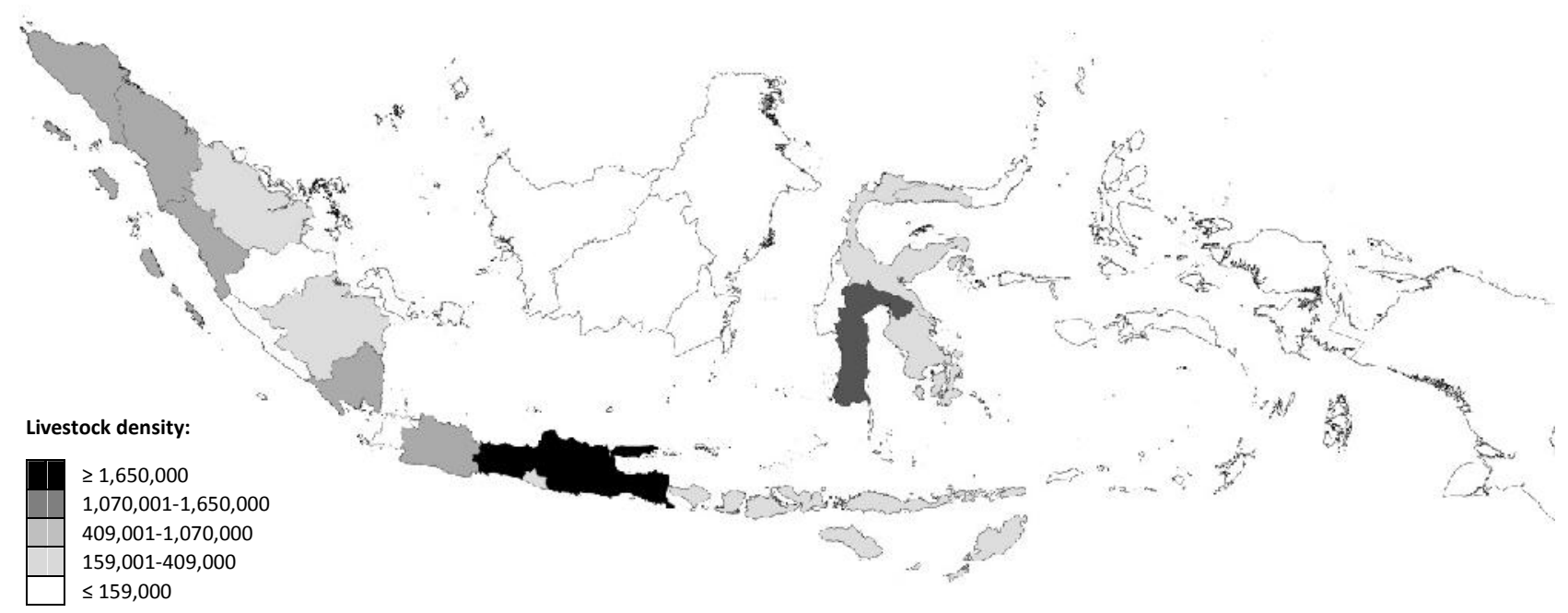

Figure 4.Population density of livestock in Indonesia

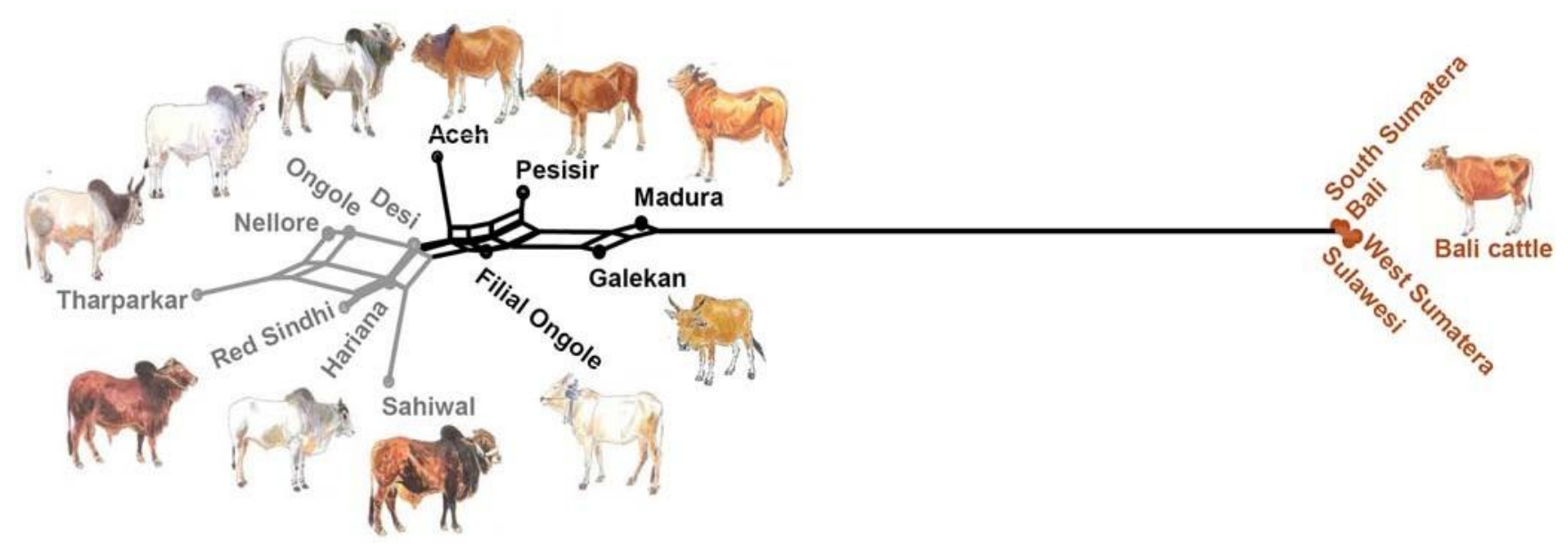

Figure 5. The relationship of Bali cattle, Indonesian local cattle and main zebu cattle of India (Mohamed et al. 2009) 
at present these two islands, as well as other places that became the center of cattle development, became the target of improving the quality of livestock through artificial insemination, which is widely used frozen semen from zebu cattle (Brahman and Brahman Cross) and taurine cattle (Simmental, Limousin, etc.). This crossing is done on the fields in an uncontrolled manner and the impact is difficult to predict in the long term. PO cattle development is a success story about improving the quality of livestock in Indonesia, which gained a new hybrid with strong adaptability to climate, feed availability, and diseases in Indonesia, and is very suitable as draught animals. However, due to daily weight gain inferior compared to other cattle, PO cattle have now also become the target of crossbreeding. While Madura cattle crossbreeding with various dairy taurine cattle show reproductive failure which offspring do not have the endurance and the production of milk as desired and descendants are no longer found.

Quality improvement through crossbreed between same cattle species is generally successful, for example PO (Bos indicus) and Brahman (Bos indicus) or Brahman Cross (Bos indicus $x$ Bos taurus). Meanwhile, a cross between cattle of different species are not always successful, because it produces male sterility and even if successful performance of reproductive females will suffer a loss of quality after a few generations, so it should always supplied the male semen purely to crossed, for example, Madura cattle (Bos javanicus x Bos indicus) with Red Danish (Bos taurus) failed to give offspring that will grow, reproduce and adapt to the local environment. Similarly, a cross between FH cattle (Bos taurus) and PO cattle (Bos indicus) that produce Grati breeds, where after a few generations the quality is much lower, so it should always be provided new stocks. Same things happens to gynecological Simpo and Limpo, where the pregnancy rate of female calf with Simmental or Limousin semen has a lower success than PO females. However, in the case of beef cattle, breeders are generally not too concerned with long-term conditions for the calves produced that are intended to be cut, not bred, so it always need to provide the frozen sperm of pure male. In the present time, the commonly males used for crossbreeding are Simmental and Limousin breeds, whereas females are from PO cattle breeds, but also has reported success with female cattle of Bali and Madura cattle. In some cases, a cross between species of cattle may also produce offspring that remain qualified after several generations, such as Madura cattle, Brahman Cross, and the ACC. Before conservation and management, it is important to recognize the level of genetic variation in cattle populations.

Another aspect that is less favorable for the development of Indonesian local cattle is the lack of effort to improve descent with the right technology. Efforts to select and get rid of unsatisfying cattle from its group are never being done, and the growth rate was never recorded. This is in addition to less favorable economic terms, can also worsen next generation. By improving the quality and quantity of Indonesian local cattle production, it is expected that the interest of local cattle breeders to maintain both will be increased, so that the Indonesian local cattle extinction can be avoided and at the same time dependence of Indonesia for beef cattle from other countries may be reduced (Sutarno 2006).

Indonesian local cattle, such as Bali cattle, have the advantage of reproduction capability and high adaptability to the local environment, but the quality and quantity of production is lower than the imported cattle (Sutarno 2006). Various government programs to improve the local cattle population so that it becomes the main source of beef cattle which include reduction of slaughtering on productive local cattle, and expand the range of interbreeding programs of local female cattle through artificial insemination (DGLS 2010c). However, the latter program became controversial because it is done directly in the field, that it triggered an uncontrolled genetic mixing, and produced offspring that have not been proven their adaptability to climate, natural feed and local disease as well as their reproductivity. Artificial insemination also reduced the period of open days (Siregar et al. 1993).

Genetic studies provide insight about the loss of genetic diversity due to inbreeding and the implications on natural populations. Conservation of genetic diversity is very important because it represents the potential evolution of a species (Frankham et al. 2002). In the case of Indonesian local cattle, especially Bali and zebu cattle, Mohamad et al. (2009) have revealed the origins of Bali cattle, as well as the level of genetic variation, inbreeding and genetic purity to determine the sub-populations that are more suitable for conservation.

\section{GENETIC MARKERS BASED SELECTION}

Cattle breeding have now reached a new scene with the nearly completed genome map of taurine cow (Elsik et al. 2009). QTLs facilitate understanding of the level of production and the behavior characteristics of beef and dairy cattle, thus providing a definite guide to selection (Friedrich et al. 2015). Meat and milk production can be increased through artificial selection. Improved genetic quality of cattle can be done with conventional methods of performance-based selection (PBS) or growth, and direct selection on the DNA by using marker assisted selection (MAS) that can recognize certain genes such as growth hormone gene and mitochondrial DNA (Sutarno 2010). Until a few years ago, the selection to obtain quality breeds was generally performed only by external appearance (phenotype). Individuals having a good phenotype are led to mate each other to obtain offsprings with good phenotype. However, this technique is not appropriate because of the environment factors, such as feed, water maintenance and management, able to affect the body appearance, but not inherited. While genetic factors that codes growth properties is inherited, so it is appropriate for the selection (Sutarno 2006).

Selection is done with a guide marker gene, which variations of DNA sequences that characterize variations in the nature of phenotype, both of which directly affect the trait (candidate gene marker approach), or indirectly through a linkage with DNA sequences which affect the 
nature of phenotype (random marker approach). Candidate gene markers approach is based on the knowledge that the selected genes involved in desirable traits, such as growth hormone gene. However, this approach is limited to characteristics known on physiological and biochemical relationships. Instead, in the random marker approach, genotypes measurements are performed on a number of loci of whole genome without knowing the influence of phenotype, with the hope that there is locus relating to the desired characteristic, so this approach is less valuable than the candidate approaches (Sutarno 2006).

Specific genes have a significant influence on growth, milk production or other specific targets. Edwards and

Page (1994) and Lande and Thompson (1990) stated that the increase in the genetic trait to $50 \%$ will occur with MAS technique. This increase occurred due to greater control of the MAS technique in the selection, thereby reducing the selection time between generations because the genes can be identified early during birth or still in the uterus. Gene markers approach have been widely used successfully for the characteristics of disease resistance, the quality and quantity of carcasses, fertility and reproduction, milk production, and the performance of growth (Sutarno 2006).

Growth is controlled by several genes, either genes with big influence (major gene) or genes with small influence (minor gene). One of the genes thought to be key genes in affecting growth is the growth hormone genes. In addition, mitochondrial DNA which is located outside the nucleus (the cytoplasm) is also considered affecting the growth since mtDNA is the controller of energy formation process (Sutarno 2010).

\section{Growth hormone gene}

Growth hormone in cattle (bovine growth hormone) has a major role in the growth, milk production, animal body composition, and is associated with a higher average growth (Winkelmann et al. 1990; Hoj et al. 1993; Cunningham 1994). Administration of growth hormone may increase the average growth of cattle (Burton et al. 1994). Increased growth is influenced by the performance of IGF-I (Armstrong et al. 1995), so the variation of these genes leads to variations in growth (Ballard et al. 1993), for example, observed in PO cattle (Sutarno 2003) as well as Composite and Hereford (Sutarno 1998). According to Schlee et al. (1994b) polymorphism in the growth hormone gene (GHG) cause differences in hormone synthesis, resulting in differences in the concentration/circulation of these hormones. This difference causes the growth variation among individuals. Thus, DNA variations on growth hormone gene can serve as a potential candidate as cattle growth feature gene markers (Sutarno 2006) (Figure $6)$.

Variations in the growth hormone gene locus of Composite cattle in Western Australia significantly affect variation of the mean growth (Sutarno et al. 1996; Sutarno 1998). Schlee et al. (1994b) found that differences in the genotype of a growth hormone gene influence circulating concentrations of growth hormone and IGF-I in the Simmental cattle. Rocha et al. (1992) found a significant association between alleles of growth hormone with weight at birth and the ridge width at birth in Brahman cattle. These variations have been reported in taurine cattle, but is still limited to a local Indonesian beef cattle (Sutarno and Junaidi 2001; Sutarno 2003).

To obtain superior Indonesian local cattle in the production of meat, it is important to acquire the marker gene from the population of local cattle thorough analysis of the combination of phenotype data (growth), genotype data (allele), as well as all supporting data which may affect growth (cattle species, sex, age, the concentration of circulating growth hormone, etc.). Cattle growth hormone gene which has been mapped is located on chromosome 19 with location-qtr Q26 (Hediger et al. 1990). This gene sequence consists of 1793 bp which was divided into five exons and is separated by four introns (Sutarno 2006). Variations of the gene encoding growth hormone has been reported in taurine cattle, for example, Red Danish dairy cattle (Hoj et al. 1993), Simmental beef cattle (Schlee et al 1994a), Hereford and Composite beef cattle (Sutarno et al. 1996; Sutarno 1998) as well as PO cattle, Bali cattle and Madura cattle (Sutarno et al. 2002, 2003). Such variations are generally caused by the deletion, substitution or insertion (Sutarno 1998, 2003).

In Simmental cattle breeds, Schlee et al. (1994a) showed that individuals which have LV (leucine/valine) genotype on their growth hormone gene is superior in achieving weight of carcass and meat quality. Polymorphisms which were detected by TaqI on its growth

ACTIONS OF GROWTII IIORMONE

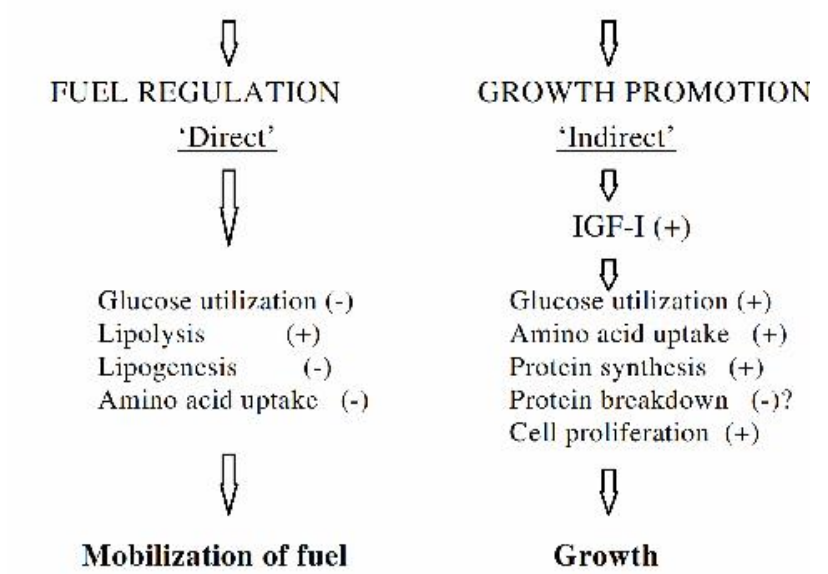

$\mathbf{A}$

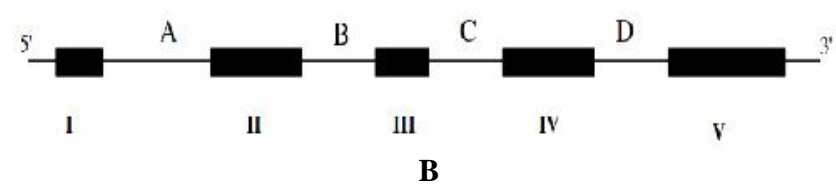

Figure 6. A. The role of growth hormone in regulating metabolites material for fuel regulation and growth; $\mathrm{B}$. The structure of growth hormone gene in cattle; The letters A, B, C and D show the introns, while the Roman numerals I, II, III, IV and V show the exons (Sutarno 1998). 


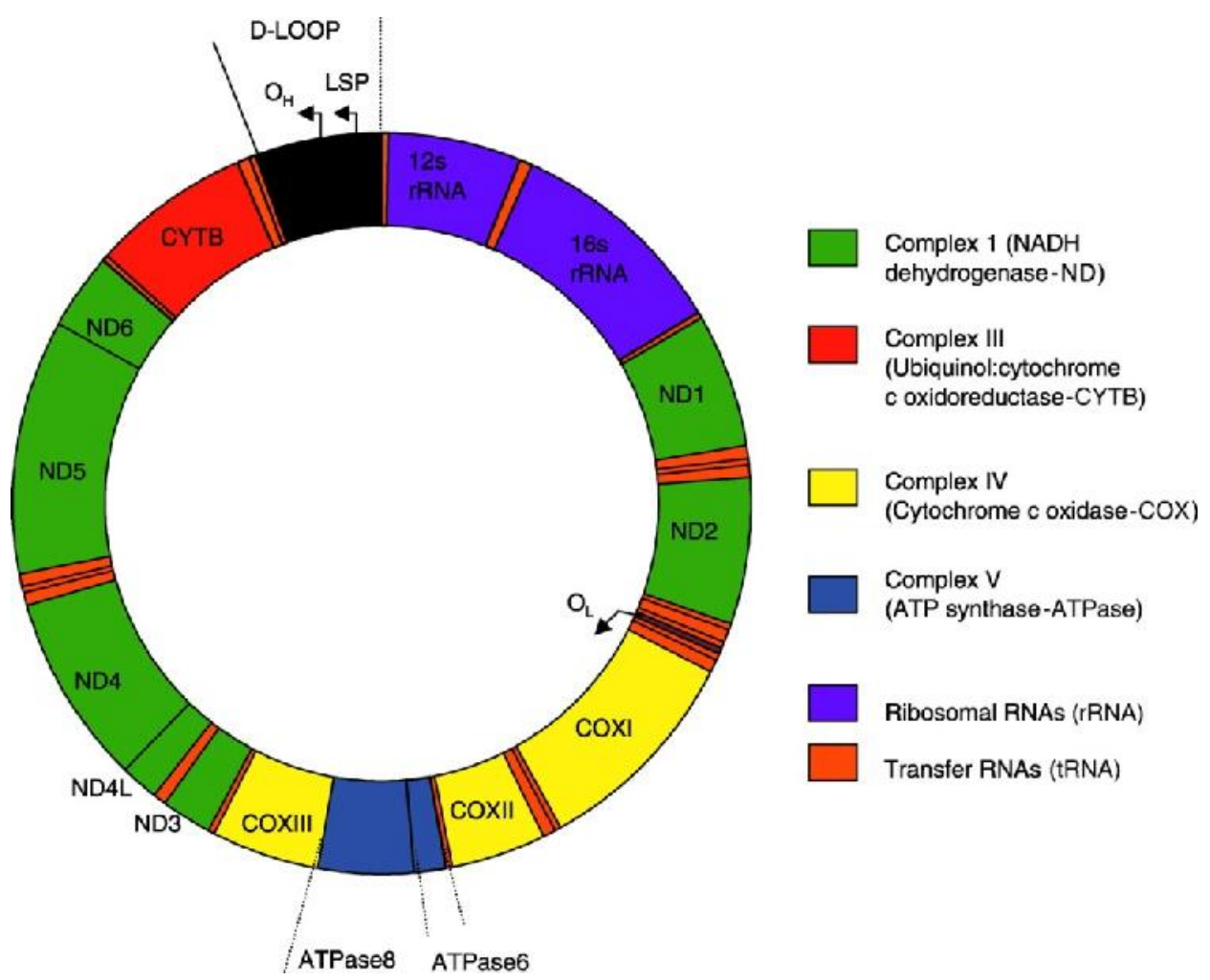

Figure 7. The mitochondrial DNA of mammals, including cattle (St John et al. 2004)

hormone gene were reported to be associated with birth weight in Brahman cattle (Rocha et al. 1992) and with growth in Korean cattle (Choi et al. 1997). Research conducted by Sutarno (1998) against Hereford cattle and Composite showed that MspI polymorphism in the growth hormone gene region between exons III and IV significantly affect the growth, in which individuals that have allele $M s p \mathrm{I}(-)$ are superior. At PO cattle, individuals who have MspI +/- heterozygous genotype has higher weight, chest circumference and body length than MspI genotype homozygous +/+ or MspI -/- (Sutarno 2003; Paputungan et al. 2013). The relationship of genotype variations in growth hormone locus with a total growth of cattle is probably caused by differences of growth hormone circulation as a result of the growth hormone gene variation (Sutarno 2006). Study of gene polymorphisms of growth hormone has also been done on some Indonesian local cattle such as Pesisir cattle (Jakaria et al. 2007), Bali cattle (Jakaria et al. 2009; Jakaria and Noor 2011), Madura cattle (Purwoko et al. 2003; Hartatik et al. 2013), PO cattle (Sutarno et al. 2005; Sutarno 2010; Paputungan et al. 2013; Rahayu et al. 2014), Sumba Ongole cattle (Anwar et al. 2015), Aceh cattle (Putra et al. 2013, 2014) and Grati dairy cattle (Maylinda 2011).

Selection to obtain superior descendants based on DNA markers such as DNA polymorphisms can provide a more accurate and efficient result (Schlee et al. 1994b). Gene variations in growth hormone gene are related to variations in growth hormone and insulin-like growth factor (IGF-I).
Then, variations of growth hormone and IGF-I have caused differences in growth, so that the encoding growth hormone gene can be used as a potential starting point as DNA markers for Indonesian local cattle breeding(Sutarno 2006).

\section{Mitochondrial DNA}

Mitochondrial DNA (mtDNA) is a genetic marker that is very useful to study the origin, genetic diversity and descendant differentiation because it has unique characteristics inherited from the female broodstock, the fast rate of evolution and the less level of recombination (Bailey et al. 1996; Liu et al. 2006; Galtier et al. 2009). Mitochondrial DNA is located outside the nucleus and is responsible for the energy formation. It affects the growth, reproduction and production characteristics in cattle (Schutz et al. 1994). MtDNA gene is a marker that is efficient, because the segments of genes that evolved differently (Zardoya and Meyer 1996; Kikkawa et al. 1997; Hassanin and Ropiquet 2004; Kartavtsev and Lee 2006).

Variations on mtDNA cattle have been reported (Sutarno and Lymbery 1997; Sutarno 2002a). MtDNA evolved faster than nuclear DNA, and even though there are thousands of copies of mitochondrial genome in each cell, nucleotide substitution occurred about five to ten times faster than the same mutation in the DNA core. Modifications and variation in mtDNA will affect the phenotype. Schutz et al. (1994) reported that there is effect of various mtDNA sequences on milk production, while 
Schutz et al. (1993) found a significant effect of substitution at nucleotide pairs (bp) no. 169 D-loop sequences in the percentage of milk fat. MtDNA variations on D-loop segment significantly affected the reproductive feature of Hereford and Composite cattle (Sutarno et al. 2002a; 2002b) (Figure 7).

Mitochondrial DNA is a marker based on the maternal pedigree that may show the family history (Ascunce et al. 2007). Research on the D-loop region of mtDNA on several breeds cattle have shown that taurine cattle ancestors came from Syria, and then spread throughout Europe (Edwards et al. 2007). MtDNA D-loop region in cattle may show hybridization to the banteng and Madura cattle (Nijman et al. 2003). Based on the sequence of mtDNA D-loop region, Aceh cattle is one cluster with Pesisir cattle and PO is zebu cattle, while Bali cattle and Madura cattle form its own separate cluster. The base composition of mtDNA D-loop region nucleotide of Aceh cattle is different from other local cattle with difference sequence from smallest to largest, i.e. from Pesisir cattle, PO cattle, Bali cattle and Madura cattle. It can be used as a marker for distinguishing and grouping of Indonesian local cattle. Aceh cattle have similarity base arrangement of nucleotide for about $94.36 \%$ with the zebu cattle, so based on the maternal line, Aceh cattle is originated from zebu cattle (Abdullah et al. 2008).

MtDNA analysis can also be used to trace relationship and genetic purity of the female parent lines. Bali cattle in Malaysia generally contain genes of other cattle, such as China's Yellow cattle, Kedah-Kelantan and Brakmas, while Bali cattle in Indonesia tend to be pure (Somarny et al. 2015). This happens because in Malaysia the Bali cattle is raised together with other breeds of cattle, while in Indonesia they are not generally raised together with other cattle (Nijman et al. 2003). Instead, Chinese Yellow cattle which are believed to be descendants of crossbreeding of taurine and zebu (Mao et al. 2006) actually contain Bali cattle genes or banteng (Chang et al. 1999). An understanding of the origin, differentiation and genetic relationships between offspring cattle is very important for the genetic management, sustainable usage and cattle conservation (Somarny et al. 2015).

However, cattle with the same genetic traits can have the performance of a much different because of differences in the management of maintenance. In Madura, Madura cattle function as beef cattle, racing cattle (karapan) and displayed cattle (sonok), each of which has different physical character and behavior, but all three were taken from generally same calf. Diversity analysis of BCKDH (Branched-chain $\alpha$-ketoacid dehydrogenase), the main enzyme complex in the inner membrane of mitochondria that metabolize valine, leucine, and isoleucine, showed no mutations associated with differences in the allotment of Madura cattle (Febriana et al. 2015).

Analysis of molecular data from mtDNA and growth hormone gene, combined with the phenotype data of cattle's growth, it is known that genotypes of cattle that is superior in the production of meat that can be used as a marker gene. Gene markers approach can be used in animal breeding to obtain superior breeds through planned crossbreed that sets parent genotype. Further development of the marker gene is that it can be used in DNA recombinant to produce growth hormone. This hormone can be used temporarily to induce growth, and furthermore towards the establishment of transgenic animals, an early detection of diseases and other phenotypic traits (Sutarno 2006).

\section{CROSSBREEDING}

Crossbreeding is an important part of cattle improvement because of the variability of environment and market demand that need to be addressed. Crossbreeds bring out heterosis effect in which to collect the new advantageous characteristics, for example crossbreeds between zebu cattle that are impervious to hot climates and taurine cattle that can grow faster. Refinement on breeding governance can improve the performance of livestock, but these characteristics are not inheritable, on the other hand, genetic improvement can be inherited. Cattle productivity is influenced by genetic and environmental factors; cattle can reach their genetic potential conditions when supported by an optimal environment (Talib et al. 2002). Environmental conditions and the livestock breeds affect the rate of growth, calving production and reproduction ability (Nugroho 2012). Cattle which are raised on the traditional system generally will experience a forage shortage due to the limited and low quality of feed, and rarely given additional feed such as concentrates and grains, so they rarely reach the optimum conditions (Wiyatna et al. 2012).

Breeders prefer crossbreeding because of the effect of heterosis where offspings will have more superior characteristic than the parent's. In crossbreeding through artificial insemination, the breeder can set all female broodstocks to give birth at relatively the same time to obtain calves of the same age. Crossbreeding can be designed to establish certain cattle breeds, according to market needs. Cattle crossbreeding cannot be done haphazardly but it must be done with clear objectives and will last over the long term from generation to generation. Because of weak control in crossbreeding, the entry of additional genetic from other cattle may frustrate the achievement of goals because too much variability in the offspring (Comerford 2014). However, a crossbreed may lead to the loss of adaptability to the local environment (Mohapatra 2004), so, ideally, an assessment of the impact of introduced livestock before it becomes a realization (Mastuti 2014). Crossbreeding to get superior calf must begin by characterizing all the characteristic of local cattle which have adapted to the local environment and predict the results to be obtained.

Performance of cattle reproduction is influenced by environmental conditions. In the semi-arid or tropical climates, zebu cattle show more superior reproductive performance than taurine cattle (Meirelles et al. 1991), but in highland or temperate zones taurine cattle have better reproductive performance (Duarte and Barbosa 1989). Some studies have reported a close relationship between 
genotype and environmental factors on the productive performance and reproduction of beef and dairy cattle (Mulder and Bijma 2005; Hammack 2009; Hammami et al. 2009). The characteristics of reproduction, first mating age, number of service per conception, open days and calving interval are the basis for determining the profitable cattle ranch (Enyew et al. 1999; Tavirimirwa et al. 2013). Age of mating and first calving is significantly affected by height (in relation to the ambient temperature), where cattle age of mating and first calving is slower in lowland (Suyadi et al. 2014). Heritability of these traits is usually low, so, including conditions and feed management; environmental factors play an important role in the variability (Olori et al. 2002).

In Indonesia, crossbreeding cattle are mostly done through artificial insemination. This activity has been known in Indonesia since 1953, and since 1980-1990, it has widely performed using semen of some foreign taurine cattle that the growth and body weight is relatively higher. However, until now the purpose of artificial insemination program is not clear yet, it will be towards the formation of a composite cattle, terminal cross, or commercial livestock. Many breeders helped the officer to the quality of livestock by crossing local cattle with Simmental or Limousin cattle. Cattle breeders like this, because the price of male offspring is very high, even though the local cattle turned into large cattle type that needs a lot of feed. In the forage shortage conditions, cattle crossbreeding be thin, poor body condition, and decline in reproductive performance, such as high number of services per conception, long time of calving interval, and low quality calf. This condition is accompanied by low production of milk and high calf mortality. On the condition of good maintenance, reproductive performance of crossbreeding cattle remains good. While on the local cattle, forage shortage conditions only lead to thin body, but still capable of estrus, ovulation and pregnant. In quantity and quality, forage is one of the important keys to the condition of crossbreeding cattle to remain good and productive (Diwyanto and Inounu 2009).

The interaction of genotype and environmental factors can be observed from the age of first calving and the first lactation in dairy cattle (Suyadi et al. 2014; Sahin et al. 2012). Nugroho (2013) reported that PO cattle showed lower feed intake, lower growth rates and lower body condition score (BCS) than Limpo crossbreed cattle. It shows that in tropical conditions, the breeds of cattle affect the growth rate. On the other hand, the chewing ability of Limousin crossbreed is better than the PO (Purnomoadi et al. 2003). In the FH dairy cattle, the age of first lactation affects total milk production during the second and third lactation. Earlier age of first calving and first breastfeeding cause lower milk production in the next lactation (Madani et al. 2008). Cattle species have no effect on this variable, even the PO cattle in lowland shows slower age of mating and age of first calving. This is due to the different levels of genetic response to environmental conditions which are critical due to lower feed intake and BCS. Bridges and Lemenager (2008) states that the low BCS in cattle causing low reproductive performance including age of first mating and first calving (Figure 8).

\section{Bali cattle}

Increased production of Bali cattle has been done through artificial insemination using frozen semen from taurine cattle such as Simmental, Limousin, Hereford, and Charolais as well as zebu cattle of Brahman breeds, up to now the best result for the rate of growth is Simmental (Diwyanto and Inounu 2009). Crossbreeding systems to improve livestock meat production utilize heterosis and exploit differences among cattle in certain characteristics (Tang et al. 2011), in the different environmental conditions (Dadi et al. 2002). However, these efforts may not have a positive impact if it is not followed by the environmental improvement. Replacement of local cattle with exotic cattle could create new problems, such as obstructed birth due to increased birth weight, low tolerance to harsh environmental conditions, and increased forage demand due to higher growth rates and larger body size (McCool 1992).

Performance of breed of cattle or its crossbreeding is not always the same in different environmental conditions. Environmental factors that most affect the livestock production are heat and humidity (Yeates et al. 1975). In tropical countries, air temperature varies depending on the altitude (Williamson and Payne 1980). Lowland is hotter than highlands. Sub-tropical taurine cattle only produce well in the highlands, while the highland area in Indonesia is relatively limited. In West Nusa Tenggara, Bali cattle calf raise in lowland and highland (>700 m) had a relatively same growth rate, while Simbal crossbreeds (Simmental x Bali cattle) have a higher growth rate in the highlands. The offspring which backcross with Simmental has a higher growth rate in the highlands and lower growth rate in the lowland, while the offspring which backcross with male Bali cattle has a higher growth rate in the lowlands (Pribadi et al. 2014).

Therefore, it is important to evaluate the factors that affect the economical properties of diverse environments to understand the proper management in hybrid system, because interaction can affect the productive efficiency (Pribadi et al. 2014). Growth characteristics such as weight at birth, weaning and yearling are economically very important in cattle production systems. Birth weight and weaned weight are affected by the parent's genetic (Meyer 1992). Weaning calf and yearling cattle are the main products of beef cattle, body weight greatly affect the selling price, as well as an important criterion in cattle breeding (Bazzi and Alipanah 2011; Ashari et al. 2012).

\section{Peranakan Ongole}

Peranakan Ongole (PO) derived from the uncontrolled crossing between Sumba Ongole cattle with local cattle in Java since the 1930s. PO cattle are a tropical species that have adapted in Indonesia, especially in East Java. Since the 1990 s, many PO cattle crossed with taurine cattle, mainly Simmental and Limousin, through artificial insemination without considering the genetic composition of descendant, so it is feared that it will affect their adaptation, reproduction and growth. But, breeders support this effort, because it gave them good calves, with faster 

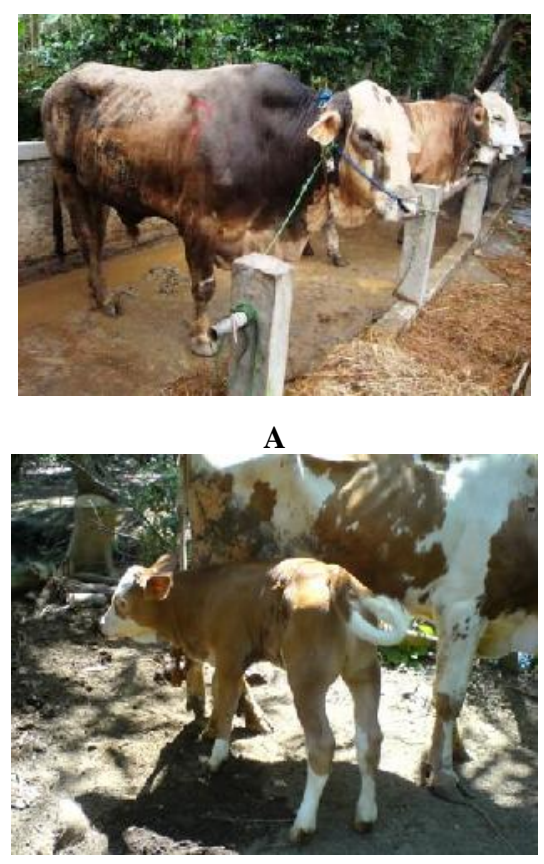

D

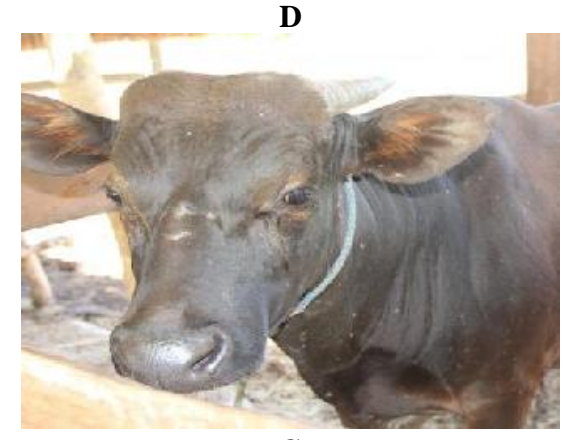

G

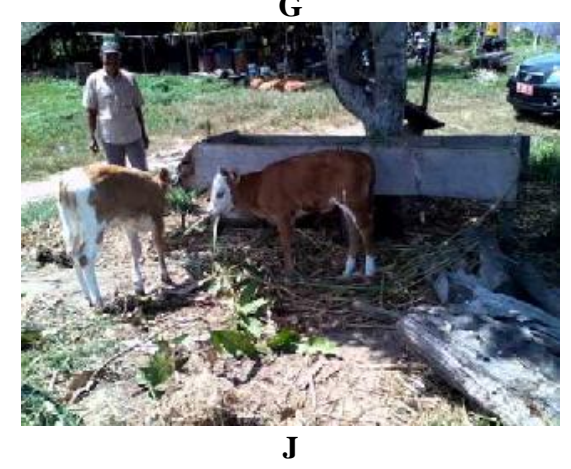

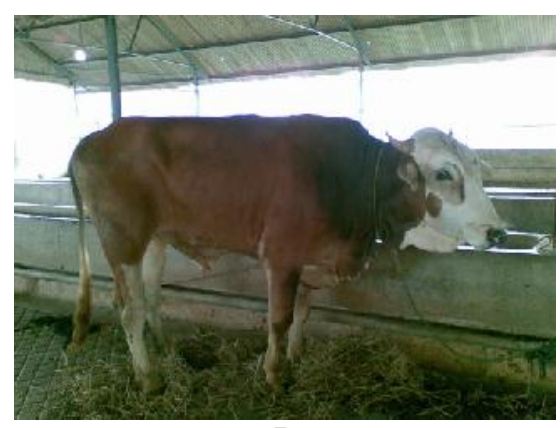

B
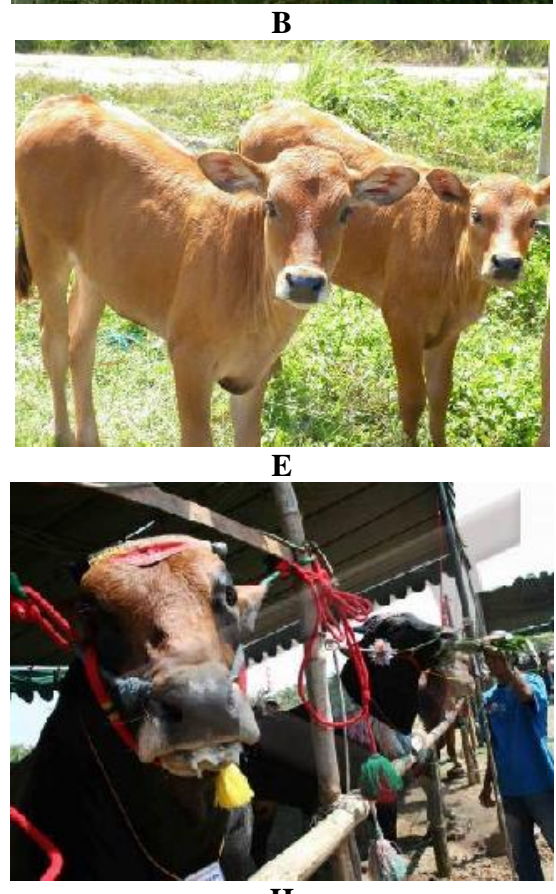

H

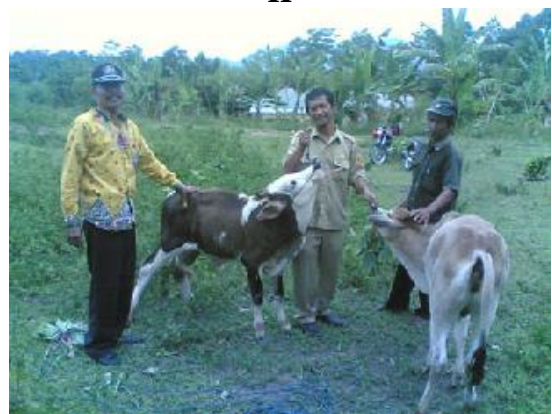

K
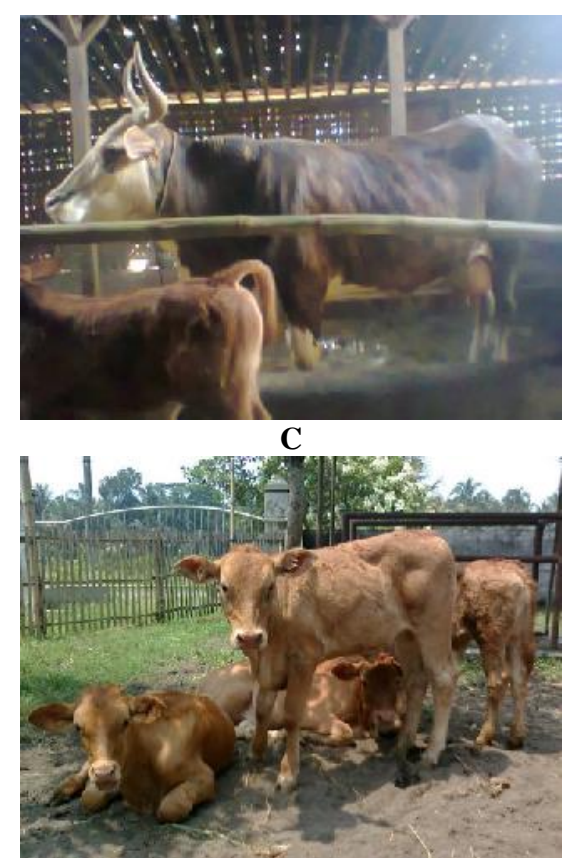

F
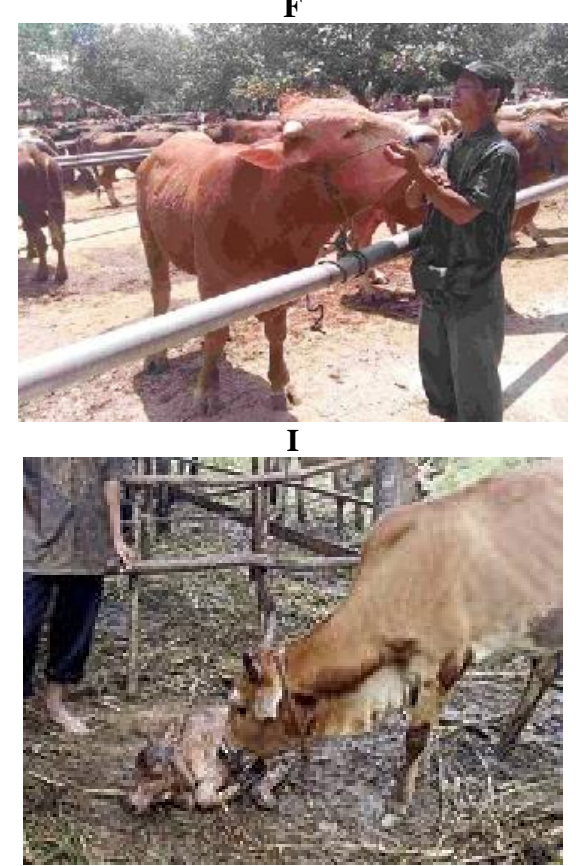

L

Figure 8. The diversity of cattle crossbreeds from artificial insemination in Indonesia. A-B. Simpo cattle (Simmental bull x PO cow) in Central Java; C. Simpo cow and its calf that produced from artificial insemination with Simmental bull in Boyolali, Central Java; D. Simpo calf and its Simpo cow that produced from artificial insemination with Simmental bull in Klaten, Central Java; E. Limbal calf (Limousin male x Bali cattle female) in Nunukan, North Borneo; F. Limousin crossbreed in Jember, East Java; G. Limad calf (Limousine bull x Madura cow) in Rote, East Nusa Tenggara; H. Limad bull in the island of Madura or locally known as Madrasin; I. Limpo cattle in Sukoharjo, Central Java; J. Calf of Simbal (Simmental bull x Bali cattle cow) in Nunukan, North Borneo; K. Calf of Simpo in Dairi, North Sumatra; L. Crossbreed calf of Brahman and local cattle in South Tapanuli, North Sumatra

growth. At the age of three years, hybrid cattle (Simpo or Limpo) are able to reach a weight of $800 \mathrm{~kg}$, while the PO cattle reach less than half of it. Conversely, PO cattle production costs less than half of the hybrid cattle (Sutarno 2006). Endrawati et al. (2010) showed that consumption of green fodder and concentrate on Simpo cattle is greater than the PO's, but if it is calculated based on metabolic body weight, it makes no different. Digestibility of feed in Simpo and PO is not different, as well as the BCS and estrous cycle. 
Limpo and Simpo cattle are widespread across Java, in the lowlands and highlands. PO cattle's first mating age is higher than Limpo cattle's. In the highlands, service per conception $(\mathrm{S} / \mathrm{C})$ is higher for Limpo and there was no significant different for open days period (DO) and calving interval period (CI), making it both more efficient to be maintained in the lowlands. Yulyanto et al. (2014) showed that the value of S/C, DO and CI between PO cattle and Limpo differ significantly, where the reproduction performance of PO cattle is better than Limpo. At PO cattle and Limpo, calving interval period and first mating are around 99-137 days. Environmental conditions and the breeds of cattle affect calving interval period and first mating (Suyadi et al. 2014). Cattle species and the average daily temperature resulted in a different interval between calving and mating. This interval is longer in the dry season than the wet season, probably because of the low quantity and quality of feed during the dry season which result of low BCS (body condition score) (Kebede et al. 2011). Service per conception ranged from 1.64 to 2.01 is affected more by climate than by species of cattle that in a tropical climate it shows higher service per conception (Kebede et al. 2011). Limpo cattle containing genetic of zebu and taurine cattle show high service per conception (Suyadi et al. 2014). The period of open days and calving interval was not significantly influenced by the breeds of cattle and environmental conditions (Suyadi et al. 2014). Performance of reproduction based on the reproduction cycle (first mating after calving, service per conception, open days and calving interval) of PO cattle is more efficient than Limpo. Altitude and breeds of cattle affect age of first mating and first calving, the first mating after calving and the number of services per conception, but not on open days and calving interval. Based on the reproduction performance, $\mathrm{PO}$ cattle and Limpo cattle are more efficient to be raised in the lowlands than highlands (Suyadi et al. 2014).

Simpo and Limpo cattle have a better growth than PO cattle's in traditional breeding. Male PO and Limpo's consumption with rice straw and concentrate in the ratio of 60: 40 is $2.8 \%$ live weight (DM basis), but the growth of PO is less than half compared to Limpo ( $0.47 \mathrm{~kg}$ per day) (Purnomoadi et al. 2003). According to Pamungkas et al. (2012), feed quality can reduce the possibility of differences in daily weight gain. For comparison, Moran (1985) recorded a daily weight gain of $0.65 \mathrm{~kg}$ per day for male PO cattle fed by fiber-based $(70 \%$ grass and $30 \%$ concentrate, DM basis) and $0.81 \mathrm{~kg}$ per day with concentrates. Cruz de Carvalho et al. (2010) reported lower growth rate of PO cattle than the Simpo given high concentrate diet. Simpo cattle have higher carcass weight and higher carcass percentage and feed cost per gain is more efficient than PO cattle's. The low rate of growth is often due to the high proportion of poor quality of forage in the diet such as straw (as the main feed, $48 \%$ in the dry season and $78 \%$ in the rainy season). Small breeder cannot afford to give fodder with energy content and high protein. But actually, legumes, grass, bran and remains of cassava is a feed of high quality and low cost (Pamungkas et al. 2012). Under the unfavorable fodder conditions, to raise
PO cattle is more profitable than Simpo or Limpo cattle (Hartati et al. 2005).

The difference in average daily gain (weight) of PO cattle, Simpo and Limpo in wet and dry seasons is not significant, although the growth rate tends to be higher in the wet season than the dry season. In contrast, the thickness of body circumference (girth) and body weight were higher in the rainy season for all cattle, where the BCS increased by $5 \%$ during the rainy season and decreased by $9 \%$ during the dry season (Pamungkas et al. 2012). Body weight was higher in the rainy season than the dry season due to provide the feed contains more protein in the rainy season than the dry season (Evitayani et al. 2004). On the other hand, the body weight of cattle at the traditional breeding is much lower than at the research station, so it has great potential to be increased (Pamungkas et al. 2012).

\section{Madura cattle}

Madura cattle quality improvement is generally done by crossbreeding between the Madura cattle with stud of Limousin cattle through artificial insemination (Wijono 2004; Hartatik 2009). These crossbreed cattle have better quality of meat production and are known locally as Madrasin or Limad cattle. Madrasin cattle's size and body weight is higher than Madura cattle. This condition is certainly less favorable primarily related to the effort of maintaining the existence of pure Madura cattle as one of Indonesian native germplasm cattle (Siswijono et al. 2014; Decree of the Director General of Livestock No. 18020/Kpts/PD.420/F2.3/02/2013 ).

Madura cattle maintained by small breeder for a variety of purposes including draught animals, life savings, producer of organic fertilizer, source of income and means of cultural celebrations such as cattle races (karapan) and beauty contest (sonok). Karapan involving livestock cattle compete with muscle strength and speed, while a beauty contest in the form of cattle dance to the traditional music beat on a long catwalk. Since 1993, Madura cattle crossed with Limousin to increase live weight. Such efforts are slowly adopted by farmers and supported by localgovernment, especially when decentralization policies implemented in Indonesia. To increase the income of farmers, local governments are now trying to stimulate cross cattle because calves from crossbreeds have high selling price. Though, it is contrary to the efforts of a national policy to preserve Madura cattle as indigenous genetic resources. Also, the result of crossbreeding will experience the possibility of losing the characteristics of livestock needed for cultural celebrations such as karapan and sonok cattle. However, Madura breeders felt that Limousin cattle crossed with Madura (Limad or Madrasin) increase body weight and more profitable than Madura cattle (Siswijono et al. 2010; Rahmawati et al. 2015). At this time the cattle Limad is an excitement for breeders who have long seen the development of Madura cattle breeding was stagnant. There is no definite count of Limad cattle population, but the number is believed to be a lot, especially in Bangkalan and Sumenep. In every exhibition of agriculture, Madrasin cattle have always been a star. 


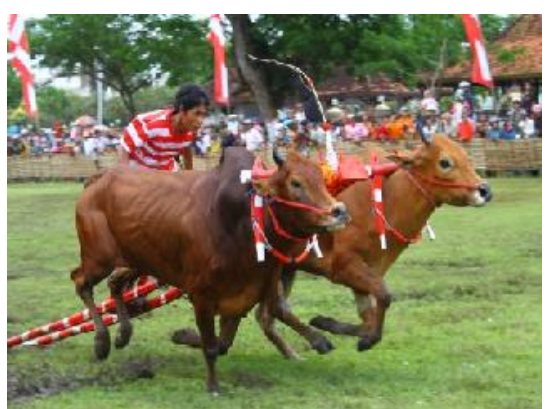

A

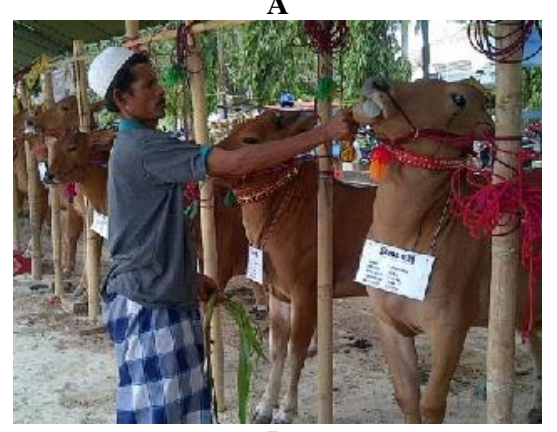

D

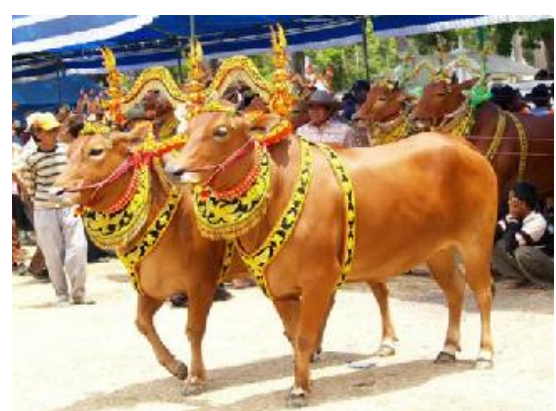

B

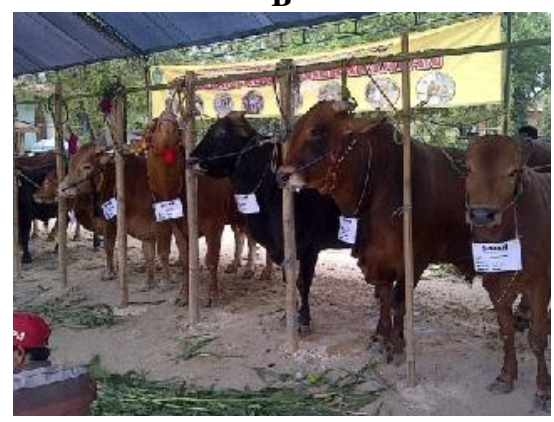

E

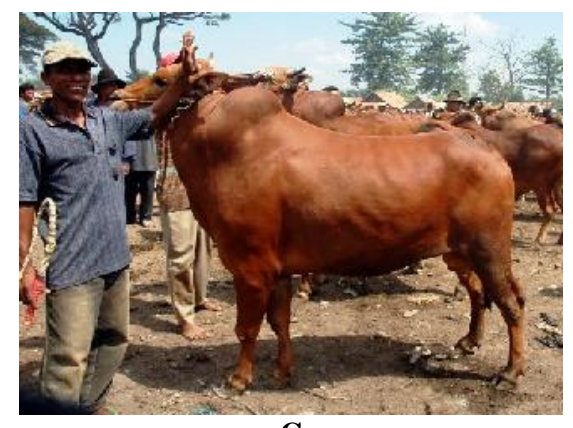

C

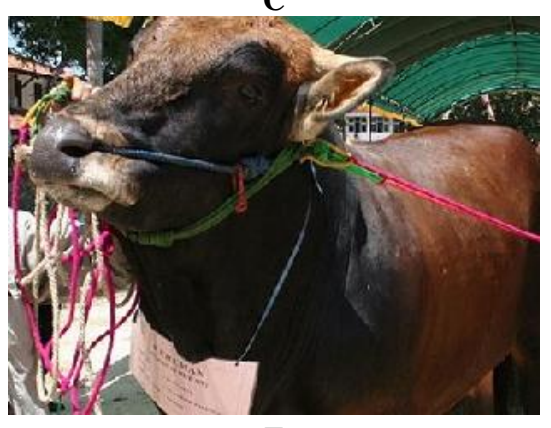

F

Figure 9.The diversity of cattle on island of Madura, East Java. A. Karapan (race) bulls; B. Sonok cattle (displayed cow); C. Madura superior cattle; D. Madura superior cattle in festivals; E. Madrasin (Limad) superior cattle in festivals; F. Performance of Madrasin bulls.

Breeding programs should include controls for crossed male cattle to avoid the possibility of uncontrolled mating; especially Madura cattle reproductive performance is greater than Madrasin, while the production of performance in Madrasin crossbreed is greater than Madura cattle. Feed conditions greatly affect calves growth, so that good quality of local feed and continuity of provision should be maintained in order to prevent negative effects on growth (Kutsiyah et al. 2003) (Figure 9).

\section{CONCLUDING REMARKS}

Self-sufficiency in beef cattle will be met if the local production and cattle population is sufficient, but the facts, the ability of Indonesian cattle population to meet the demands continues to decline, year by year. Crossbreeding between exotic cattle and Indonesian local cattle is a shortcut to increase beef production. These crossbreeding cattle have size and weight gain higher than local cattle but needs higher cost of maintenance, that the economic benefits are not much different. On the other hand, the crossbreeds have not a clear direction, and it is feared that it is not sustainable because the cattle produced has lower climate durability and lower reproductive capacity than the existing local cattle. Scientists believe that the sustainability of beef and dairy cattle supply is highly dependent on an understanding of the diversity, characteristics and use of local genetic resources in developing countries that have not been developed. Indonesia has enough local cattle, some of which have the performance of a very satisfactory and well adapted to the dry climate, to limited fodder, and to various tropical diseases, namely Bali cattle, PO and Madura cattle, in addition there are also local cattle with more limited population, namely: Aceh cattle, Pesisir cattle, Rancah cattle, Jabres cattle, Rambon cattle, Galekan cattle and dairy Grati cattle. However, along with the broader and easier service of artificial insemination, the pattern of breeds began to change, which initially the cattle are traditionally raised as draught animals and as life savings turned into semi-intensive system with orientation for beef cattle (meat), so that the performance of crossbreeds descendant of local cattle crossed with male Simmental and Limousin cattle are preferred because of the growth rate and maximum weight is much higher.

Theoretically, crossbreeds between different species of cattle would produce sterile males, while females would decrease the ability of reproduction from generation to generation. This crossbreed cattle descent proved to be less able to adapt to the tropical climate conditions, natural feed and local diseases. Thus, allowing the continuation of crossbreeding with cattle stud taurine, for example, Simmental and Limousin, against the local female cattle is the gamble for the future of Indonesian meat supply. However, proponents of these programs argue that such concerns are exaggerated, as evidenced in northern Australia, the uncontrolled genetic mixing in pasture among the various breeds of taurine and zebu cattle generate sustainable calf and become one of the main cattle which were exported in the last 30 years, namely Australian Commercial Cross (ACC) cattle. The desire to 
maintain crossbreeding cattle, such as Simpo and Limpo, continues to rise. Studies in 2008 showed that in Central Java the population ratio of local PO cattle with crossbreeding cattle (Simpo and Limpo) is $51.93 \%$ and $48.07 \%$, while in Yogyakarta is $25.75 \%$ and $74.25 \%$. This shows that the PO cattle population tends to decrease drastically, while the crossbreeding cattle population increased. In terms of meat production, to maintain Simpo and Limpo cattle is quite positive, but from the aspect of environmental capacity, increase in population, and the conservation of local cattle as national germplasm, it is very detrimental. If this continues, then in 20 years to come, PO cattle which proved adaptive to climate conditions and tropical environment are expected to become extinct. Ironically, PO cattle itself is the result of uncontrolled crossbreed between Sumba Ongole cattle and old Java cattle. The presence of SO cattle caused extinction of the old Javanese cattle, but this mating produces PO's offspring sustainable cattle, because both species is zebu. Extinction of local cattle will cause full dependence of breeding stock of imported cattle. At this time, the deficit of beef cattle population in Indonesia is only $25-30 \%$, but in the next 10 years, it will increase to about $50 \%$. Currently, feeder of Brahman Cross and the Australian Commercial Cross cattle imported from Australia dominate the market for fattening ranch. This leads to the ideals of Indonesian people to be independent and sovereign in food demand will be far from reality.

\section{REFERENCES}

AAK. 1995. Practical Guide of Cattle Farming. Kanisius, Yogyakarta. [Indonesian]

Abdullah MAN, Noor RR, Martojo H, Solihin DD, Handiwirawan E. 2007. Phenotypic diversity of Aceh cattle in Nanggroe Aceh Darussalam. J Indon Trop Anim Agric 32 (1): 11-21. [Indonesian]

Abdullah MAN. 2008. Genetic Characterization of Aceh cattle using Phenotypic Diversity Analysis on D-loop region of Mitochondrial DNA and DNA Microsatellite. [Dissertation].School of Graduates. Bogor Agricultural University. Bogor. [Indonesian]

Achilli A, Bonfiglio S, Olivieri A, Malusà A, Pala M, Kashani BH et al. 2009. The multifaceted origin of taurine cattle reflected by the mitochondrial genome. PLoS ONE 4 (6): e5753. DOI: 10.1371/journal.pone.0005753

Adiwinarti R, Fahira UR, Lestari CMS. 2011. The growth of Java bulls fed rice straw and concentrates containing different levels of protein. JITV 16 (4): 260-265. [Indonesian]

Adrial. 2010. Potential and development efforts of Pesisir cattle in West Sumatra. Jurnal Penelitian dan Pengembangan Pertanian 29 (2): 66 72. [Indonesian]

Ajmone-Marsan P, Garcia JF, Lenstra JA. 2010. On the origin of cattle: how aurochs became cattle and colonized the world. Evol Anthropol 19: 148-157.

Amin M. 2010. Intervention of genetic flow of the foreign cattle toward diversity of phenotype expressions of local cattle in the District of Banyuwangi. Biodiversitas 10: 69-74.

AMLC [Australian Meat and Livestock Corporation]. 1991. A Workshop for tropical feedlot managers: An Introductory Workshop for Feedlot Managers in the Philippines. Australian Meat and Livestock Corporation, Perth Western, Australia.

Anwar S, Agung PP, Wulandari AS, Sudiro A, Said S, Tappa B. 2015 Detection of growth hormone (GH-MspI) gene polymorphism in Sumba Ongole (SO) cattle. Pros Sem Nas Masy Biodiv Indon 1: 398403. [Indonesian]

Anwar. 2004. Diversity of External Character and Microsatellite DNA of Pesisir Cattle West Sumatra. [Dissertation]. School of Graduates.
Bogor Agricultural University. Bogor. [Indonesian]

Armstrong JD, Harvey RW, Poore MA, Simpson RB, Miller DC, Gregory GM, Hartnell GF. 1995. Recombinan bovine somatotropin increases milk yield and calf gain in diverse breeds of beef cattle: associated changes in hormones and indices of metabolism. J Anim Sci 73: 3051-3061.

Aryogi, Romjali E. 2009. Potential, utilization and development constraints of the local beef cattle as a germplasm wealth of Indonesia. National Workshop on the Management and Conservation of Genetic Resources in Indonesia: Economic Benefits to Achieve National Defense. Centre for Research and Development of Animal Husbandry, Bogor. [Indonesian]

Ascunce MS, Kitchen A, Schmidt PR, Miyamoto MM, Mulligan CJ. 2007. An unusual pattern of ancient mitochondrial DNA haplogroups in northern African Cattle. Zool Stud 46 (1): 123-125

Ashari M, Busono W, Nuryadi, Nurgiatiningsih A. 2012. Analysis of chromosome and karyotype in Bali cattle and Simmental-Bali (Simbal) crossbred. Pak J Biol Sci 15: 736-741.

Atmakusuma J, Harmini, Winandi R. 2014. Is it possible be realized meat self-sufficiency? Risalah Kebijakan Pertanian dan Lingkungan 1 (2): 105-109. [Indonesian]

Baig M, Beja-Pereira A, Mohammad R, Kulkarni K, Farah S, Luikart G. 2005. Phylogeography and origin of Indian domestic cattle. Curr Sci 89: $38-40$.

Bailey JF, Healy B, Jianli H, Sherchand L, Pradhan SL, Tsendsuren T, Foggin JM, Gaillard C, Steane D, Zakharov I, Bradley DG. 1996. Genetic variation of mitochondrial DNA within domestic yak populations. Proceedings of the Third International Congress on Yak held in Lhasa, P.R. China, 4-9 September 2000

Bali Governor Regulation No. 45/2004 about: Conservation of Bali cattle

Ballard FJ, Francis GL, Walton PE, Knowles SE, Owens PC, Read LC, Tomas FM. 1993. Modification of animal growth with growth hormone and insulin-like growth factors. Aust J Agric Res 44: 567577.

Banerjee GC. 1978. Animal Husbandry. Oxford and IBH Publishing Co, New Delhi.

Bappenas. 2007. Animal Feed. Rural Community Economic Development Project-Bappenas, Jakarta. [Indonesian]

Barbosa PF, Duarte FAM. 1989. Cross breeding and new cattle breeds in Brazil. Braz J Genet 12, Suppl 3: 257-301.

Bazzi H, Alipanah M. 2011. The effects of some environment factors on the weaning weight of Sistani beef calves. J Anim Vet Advan 10 (11): 1480-1483.

BBIBS. 2015. Freisian Holstein (FH) Catalogues. Singosari National Artificial Center, Malang. http://bbibsingosari.com/katalog/ friesien_holstein_(fh)/ [October 2, 2015]

Blakely J, Bade DH. 1998. The Science of Animal Husbandry. 8th ed. Prentice-Hall, Inc. New York.

Bollongino R, Burger J, Powell A, Mashkour M, Vigne JD, Thomas MG. 2012. Modern taurine cattle descended from small number of NearEastern founders. Mol Biol Evol 29 (9): 2101-2104.

BPPV Bukittinggi. 2013. Monitoring Reports and Jembrana Disease Diagnosis in the Working Area of the Research Center for Veterinary of Bukittinggi in 2013. Research Center for Veterinary, Bukittinggi. [Indonesian]

BPS. 2014. Preliminary figures of 2013 Agricultural Census Results. BPS, Jakarta. st2013.bps.go.id [2 Oktober 2015] [Indonesian]

Bradshaw CJA, Brook BW. 2007. Ecological-economic models of sustainable harvest for an endangered but exotic megaherbivore in northern Australia. Nat Res Mod 20 (1): 129-156.

Bridges A, Lemenager R. 2008.Impact of Body Condition at Calving on Reproductive and Productivity in Beef Cattle. Extension Specialist, Reproduction, Dept. Anim. Sci, Purdue University and Extension Beef Specialist, Department of Animal Sciences, Purdue University, Purdue.

Budiarso IT, Hardjosworo S. 1976.Jembrana disease in Bali cattle. Aust Vet J 52 (2): 97.

Burton JL, McBride BW, Block E, Glimm DR, Kennelly JJ. 1994. A review of bovine growth hormone. Canadian J Anim Sci 74: 167-201.

Chang H, Miao Z.R, Geng S.M, Wu B, Hashiguchi T, Meada Y. 1999. Studies on phylon of native cattle populations in East and South of Central Asia. Jiangsu Agric Res 20: 42-47.

Chen S, Lin BZ, Baig M, Mitra B, Lopes RJ, Santos AM, Magee DA, Azevedo M, Tarroso P, Sasazaki S et al. 2010. Zebu cattle are an exclusive legacy of the South Asia Neolithic. Mol Biol Evol 27: 1-6.

Choi YJ, Yim DS, Cho JS, Cho BD, Na KJ, Balk MG. 1997. Analysis of 
Restriction Fragment Length Polymorphism in the Bovine Growth Hormone Gene related to growth performance and carcass quality of Korean Native Cattle. Meat Sci 45: 405-410.

Circular of East Java Governor No. 524/8838/023/2010 about: Prohibition of Importation and Distribution of Cattle, Meat and Offal imports. [Indonesian]

Comerford J. 2014. Crossbreeding is a Good Idea. PennState Extention http://extension.psu.edu/animals/beef/reproduction/articles/crossbreed ing-is-a-good-idea [2 October 2015]

Copland J. 1996. Bali Cattle: Origins in Indonesia. In: Wilcox GE, Soeharsono S, Darma DMN, Copland JW. ACIAR Proceeding. 75: 29-33.

Cruz de Carvalho M, Soeparno, Ngadiyono N. 2010. Growth and carcass production of Ongole crossbred cattle and Simmental Ongole crossbred cattle reared in a feedlot system. Buletin Peternakan 34 (1): $38-46$.

Cunningham EP. 1994. The use of bovine somatotropin in milk production-a review [Review]. Irish Vet J 47: 207-210.

Dadi H, Jordan GF, Schoeman SJ, van der Westhuizen J. 2002. The effect of Charolis and Hereford sires and stright bred and crossbred dams on pre weaning growth of calves. S A J Anim Sci 32 (1): 38-43.

Dahlanuddin DV, Liang TJB, Adams DB. 2003. An exploration of risk factors for bovine spongiform encephalopathy in ruminant production system in the tropics. Rev Sci Tech Off Int Epiz 22: 271-281.

Damayanti R. 1995. Subclinical malignant catarrhal fever cases in Bali cattle detected in some abattoirs by means of histopathological examination. Jurnal Ilmu Ternak dan Veteriner 1 (2): 129-135. [Indonesian]

Decree of the Director General of Livestock No. 18020/Kpts/PD.420/F2.3/02/2013 about: Guidelines for Implementation of Beef Cattle Breeding in Pulo Raya, Sapudi Island, and Nusa Penida Island. [Indonesian]

Decree of the East Java Governor No. 188/Kpts/013/2010.The location for the Conservation and Utilization of Genetic Resources of Madura Cattle. [Indonesian]

Decree of the Minister of Agriculture of the Republic of Indonesia No. 1051/Kpts/SR.120/10/2014 about: Determination of Pasundan Cattle Clumps. [Indonesian]

Decree of the Minister of Agriculture of the Republic of Indonesia No. 2842/Kpts/LB.430/8/2012 about: Determination of Jabres Cattle Clumps. [Indonesian]

Derajat MG. 2014. Appearance of Body Conformation Characteristics in Beef Cattle based on Gender in Rancah Sub-District, Ciamis District. [Hon. Thesis]. Faculty of Animal Husbandry, Padjadjaran University, Sumedang [Indonesian]

DGLS [Director General of Livestock Services]. 2003. National Report on Animal Genetic Resources Indonesia; A Strategic Policy Document. Director General of Livestock Services, Jakarta. [Indonesian]

DGLS [Director General of Livestock Services]. 2010a. Genera Guidelines for Self-Sufficiency Beef Program in 2014. Director General of Livestock Services, Jakarta. [Indonesian]

DGLS [Director General of Livestock Services]. 2010b. Blue Print of Self-Sufficiency Beef Program in 2014. Director General of Livestock Services, Jakarta [Indonesian]

DGLSAH [Director General of Livestock Services and Animal Healts] 2015. Guidelines for the Implementation of Strengthening Native/Local Cattle Breeding in Selected Island (Pulau Raya, Sapudi Island and Nusa Penida Island) and the Strengthening of Beef Cattle Breeding in Selected Districts (Siak, West Pasaman, South Lampung, Kebumen, Barito Kuala, Barru, Gunung Kidul, and Central Lombok) Director General of Livestock Services and Animal Healts, Jakarta. [Indonesian]

DGLSAH [Director General of Livestock Services and Animal Healts] 2014. Preliminary figures of Population and Livestock Production in Indonesia in 2014. Director General of Livestock Services and Animal Healts, Jakarta. [Indonesian]

Diwyanto K, Inounu I. 2009.The impact of crossbreeding on productive performance of beef cattle. Wartazoa 19 (2): 93-102 [Indonesian]

Diwyanto K, Praharani L. 2010. Reproduction management and breeding strategies to improve productivity and quality of cattle.Proceeding of the Conservation and Improvement of World Indigenous Cattle. Bali, 3-4 September 2010.

Edwards C. J, R. Bollongino, A. Scheu, A. Chamberlain, A. Tresset et al 2007. Mitochondrial DNA analysis shows a Near Eastern Neolithic origin for domestic cattle and no indication of domestication of European aurochs. Proc R Soc B 274: 1377-1385.
Edwards MD, Page NJ. 1994. Evaluation of marker assisted selection through computer simulation. Theor Appl Genet 88: 376-382.

Elsik CG, Tellam RL, Worley KC. 2009. The genome sequence of taurine cattle: A window to ruminant biology and evolution. Science 324 (5926): 522-528.

Endrawati E, Baliarti E, Budhi SPS. 2010. Performance of SimmentalOngole crossbreed cow and Ongole crossbreed cow feed with forage and concentrate feed. Buletin Peternakan 34 (2): 86-93

Entwistle K, Lindsay DR (ed). 2003. Strategies to improve Bali cattle in eastern Indonesia. ACIAR Proceedings No. 110, Aciar, Canberra.

Enyew N, Bränänag E, Rottmann OJ, 1999. Reproductive performance and herd life of crossbred dairy cattle with different levels European inheritance in Ethiopia. Proceedings of the 7th annual conference of Ethiopian Society of Animal Production (ESAP), Addis Ababa, Ethiopia, 65-76.

Evitayani, Warly L, Fariani A, Ichinohe T, Fujihara T. 2004. Seasonal changes in nutritive value of some grass species in West Sumatra, Indonesia. Asian-Aust J Anim Sci 17: 1663-1668.

FAO [Feed and Agriculture Organization]. 2000. World Watch List for Domestic Animal Diversity. 3rd ed. FAO, Rome.

Febriana A, Farajallah A, Perwitasari D. 2015. Indel incident simultaneously on the intron 7 Gen branched-chain $\alpha$-keto acid dehydrogenase E1a (BCKDHA) in Madura cattle. Jurnal Ilmu Pertanian Indonesia 20 (2): 97-102. [Indonesian]

Felius M, Beerling ML, Buchanan DS, Theunissen B, Koolmees PA, Lenstra JA. 2014. On the history of cattle genetic resources. Diversity 6: 705-750.

Frankel O, Soule M. 1981.Conservation and Evolution. Cambridge University Press, Cambridge.

Frankham R, Briscoe DA, Ballou JD. 2002. Introduction to conservation genetics. Cambridge University Press, New York, New York, USA.

Friedrich J, Brand B, Schwerin M. 2015.Genetics of cattle temperament and its impact on livestock production and breeding-a review. Archiv Fur Tierzucht 58: 13-21.

Friend J, Bishop D. 1978. Cattle World. Blandford Press, Dorset.

Galtier N, Nabbholz B, Glemin S, Hurst G.D.D. 2009. Mitochondrial DNA as a marker of molecular diversity: a reappraisal. Mol. Ecol. 18: 4541-4550.

Groeneveld LF, Lenstra JA, Eding H, Toro MA, Scherf B, Pilling D, Negrini R, Finlay EK, Jianlin H, Groeneveld E et al. 2010. Genetic diversity in farm animals: A review. Anim Genet 41: 6-31.

Gunawan (ed). 2008. Maintenance Instructions for Brahman Cross Cattle. BPTU Sembawa, Directorate General of Livestock, Palembang. [Indonesian]

Hafid HH. 1998. Production Performance of Australian Commercial Cross Cattle Reared in Feedlots with Different Conditions of Calves Age and Fattening Time [M.Sc. Thesis]. Program of Graduates, Bogor Agricultural University, Bogor. [Indonesian]

Hammack SP. 2009. Texas Adapted Genetic Strategies for Beef Cattle II: Genetic-Environmental Interaction. Agrilife Extention.Texas A \& M System. No. E-187.

Hammami H, Rekik B, Gengler N. 2009. Genotype by environment interaction in dairy cattle.Biotechnol.Agron. Soc. Environ. 13 (1): 155-164.

Handiwirawan E, Subandriyo. 2004. Potential diversity of genetic resources of Bali cattle. Wartazoa 14 (3): 107-115. [Indonesian]

Hannotte O, Jianlin H. 2005. Genetic characterization of livestock populations and its use in conservation decision making. In: Ruane J, Sannino A (eds.). The Role of Biotechnology in Exploring and Protecting Genetic Resources. FAO, Rome.

Hardjosubroto W. 2004.Alternative policy of sustainable management of genetic resources of local beef cattle in the local livestock breeding system. Wartazoa 14 (3): 93-97. [Indonesian]

Hartati, Mariyono, Wijono DB. 2005. The response of growing Peranakan Ongole Cattle and the crossbred at feed low external input based. Proceedings of the National Seminar on Technology of Animal Husbandry and Veterinary 2005.Research Center for Veterinary, Bogor. [Indonesian]

Hartatik T, Volkandari SD, Rachmana MP, Sumadi. 2013. Polymorphism leu/val of growth hormone gene identified from Limousin cross local cattle in Indonesia. The 3rd International Conference on Sustainable Future for Human Security SUSTAIN 2012. Procedia Environ Sci 17: 105-108.

Hassanin A, Ropiquet A. 2004. Molecular phylogeny of the Tribe Bovini (Bovidae, Bovinae) and the taxonomic status of the Kouprey, Bos sauveli Urbain 1937. Mol Phylogenet Evol 33: 896-907. 
Hediger R, Johnson S. E, Barendse W, Drinkwater R. D, Moore S. S, Hetzel J. 1990.Assignment of the growth hormone gene locus to $19 \mathrm{q} 26$-qter in cattle and to 11q25-qter in sheep by in situ hybridization. Genomics 8 171-174.

Helmer D, Gourichon L, Monchot H, Peters J, Saña Segui M. 2005.Identifying early domestic cattle from prepottery Neolithic sites on the middle Euphrates using sexual dimorphism. In: Vigne JD Peters J, Helmer D (eds.). The First Steps of Animal Domestication.Oxbow Books, Oxford, UK.

Hendri Y. 2013. Development of Pesisir Cattle as a local bred of West Sumatra. J Litbang Pert 32 (1): 39-45 [Indonesian]

Hilmia N, Noor RR, Sumantri C, Gurnadi RE, Priyanto R. 2013 Productivity and genetic diversity of local cattle in Ciamis West Java. J Indon Trop Anim Agric 38 (1): 10-19.

Ho SY, Larson G, Edwards CJ, Heupink TH, Lakin KE, Holland PW, Shapiro B. 2008. Correlating Bayesian date estimates with climatic events and domestication using a bovine case study. Biol Lett 4: 370374.

Hoj S, Fredholm M, Larsen NJ, Nielsen VH. (1993). Growth hormone gene polymorphism associated with selection for milk fat production in lines of cattle. Anim Genetics 24: 91-96.

Hosen N. 2006. Developmental prospects of local beef cattle in West Sumatra. Proceedings of the National Seminar on Revitalization of Local Potential to Achieve Self-Sufficiency of Meat 2010, in the framework of Sustainable Animal Husbandry Development and Improvement of Public Welfare, Padang, 11-12 September 2006. [Indonesian]

Huitema H. 1986. Animal Husbandry in the Tropics, Economic Meaning and Ability. Yayasan Obor Indonesia and PT Gramedia, Jakarta [Indonesian]

ILRI [International Livestock Research Institute]. 1995. Global Agenda for Livestock Research. Proceedings of the Consultation for the South-East Asia Region. 10-13 May 1995 IRRI, Los Banos, The Philippines.

Indonesian Law No. 18/2009 on Animal Husbandry and Animal Health [Indonesian]

Indrijani, Arifin J, Dudi, Wendry SP, Romi Z, Hilmia. 2012. Study on Identification of Local Cattle of West Java to Support SelfSufficiency Beef. [Research Report].Office of Animal Husbandry of West Java Province, Bandung. [Indonesian]

Jakaria, Duryadi D, Noor RR, Tappa B, Martojo H. 2007. The relationship of MspI Growth Hormone Gene polymorphism and body weight and body measurements of West Sumatera Pesisir Cattle.J Indon Trop Anim Agric 32 (1): 33-40. [Indonesian]

Jakaria, Noor RR. 2011. Analysis on Alu-I growth hormone (GHAlu-I) gene in Bali cattle. J Indon Trop Anim Agric 36 (2): 77-82.

Johari S, Kurnianto E, Sutopo, Aminah S. 2007. Diversity of blood protein as biogenetic parameter in Java cattle. J Indon Trop Anim Agric 32 (2): 112-118. [Indonesian]

Kartavtsev YP, Lee JS. 2006. Analysis of nucleotide diversity at the cytochrome $\mathrm{b}$ and cytochrome oxidase 1 genes at the population, species, and genus levels. Genetica 4: 437-461.

Kebede G, Kebede M, Midexa T, Eshetu S. 2011. Comparative reproductive performance of Horro (Zebu) with Horro x Friesian and Horro x Jersey females in sub humid environments of Bako.Livestock Res for Rural Development, 23 http://www.lrrd.org/lrrd23/8/Kebe23171.htm.

Khasrad, Ningrat RWS. 2010. Improving carcass quality of indigenous cattle of West Sumatra fed local feed resources. Pakistan J Nutr 9 (8) 822-826.

Kikkawa Y, Amano T, Suzuki H, 1995: Analysis of genetic diversity of domestic cattle in East and Southeast Asia in terms of variations in restriction sites and sequences of mitochondrial DNA. Biochem Genet 33 51-60.

Kikkawa Y, Takada T, Sutopo, Nomura K, Namikawa T, Yonekawa H, Amano T. 2003. Phylogenies using mtDNA and SRY provide evidence for male-mediated introgession in Asian domestic cattle. Anim Genet 34 96-101.

Kikkawa Y, Yonekawa H, Suzuki H, Amano T. 1997. Analysis of genetic diversity of domestic water buffaloes and anoas based on variations in the mitochondrial gene for cytochrome b. Anim Genet 28: 195-201.

Kutsiyah F, Kusmartono, Susilawati T. 2003. Comparative study of the productivity of Madura Cattle and Its crossbreed with Limousin in Madura island. JITV 8 (2): 98-106. [Indonesian]

Kutsiyah F. 2012. Analysis of beef cattle breeding on the island of Madura. Wartazoa 22 (3): 113-126. [Indonesian]
Lande R, Thompson R. 1990. Efficiency of marker-assisted selection in the improvement of quantitative traits. Genetics 124, 743-756.

Lenstra JA, Bradley DG. 1999. Systematics and phylogeny of cattle. In: Fries R, Ruvinsky A (eds) The Genetics of Cattle. CAB International, Wallingford.

Lestari CMS. 2012. Exploration Potential of Jabres Cattle Production, as Local Beef with Method of In vivo and Non-invasive to the In situ and Ex situ Maintenance. [Dissertation].School of Graduates, University of Diponegoro, Semarang. [Indonesian]

Liu RY, Yang GS, Lei CZ. 2006. The genetic diversity of mtDNA DLoop and the origin of Chinese goats. Acta Genetica Sinica33: 420428.

Long JA. 2008. Reproductive biotechnology and gene mapping: Tools for conserving rare breeds of livestock. Reprod. Dom. Anim. 43: 83-88.

MacHugh D.E. 1996. Molecular biogeography and genetic structure of domesticated cattle [M.Sc. Thesis]. Department of Genetics. Trinity College, Univ. Dublin, Dublin.

Madani T, Yakhlef H, Marie M. 2008. Effect of age at first calving on lactation and reproduction of dairy cows reared in semi arid region of Algeria. Livest Res Rural Dev 20 (6): 121-129.

Mahbubi A. 2014. Madura development program as a cattle island; perspective of sustainable cattle supply chain management. Agronomika 3 (2): 98-109. [Indonesian]

Maintenance of Dairy Cow Lactation in Lowlands Area

Mao YJ, Chang H, Yang ZP, Xu M, Zhang L, Chang GB. 2006. The genetic diversity and phylogenetics status of Luxi cattle. Agric Sci in China. 5: 629-634.

Margana S. 2007. Java's last frontier : the struggle for hegemony of Blambangan, c. 1763-1813. [Ph.D. Dissertation]. Faculty of Arts, Leiden University, The Nederland.

Mariani R. 2013. Prospects and Challenges of Pesisir Cattle Development. Harian Padang Ekpress. http://padangekpress.co.id/ 2news=nberita\&id.2862. [17 Februari 2013. [Indonesian]

Martojo H. 2003. Indigenous Bali Cattle: The Best Suited Cattle Breed for Sustainable Small Farms in Indonesia. Laboratory of Animal Breeding and Genetics, Faculty of Animal Science, Bogor Agricultural University, Bogor. [Indonesian]

Martojo H. 2012. Indigenous Bali Cattle is Most Suitable for Sustainable Small Farming in Indonesia. Reprod Domest Anim 47: 10-14.

Mason IL. 1988. World Dictionary of Livestock Breeds. 3rd edn. CAB International; Wallingford, CT, USA.

Mastuti WTS. 2014. Impact Assessment of Exotic Cattle Breeds on Indigenous Cattle Genetic Resources, Farming Systems, and Rural Livelihoods in Indonesia. [Ph.D. Dissertation]. Wageningen University, Wageningen.

Maylinda S. 2011. Genetic polymorphism of growth hormone locus and its associations with body weight in Grati dairy cows. Int J Biotechnol Mol Biol Res 2: 117-120.

McCool C, 1992: Buffalo and Bali cattle-exploiting their reproductive behaviour and physiology. Trop Anim Health Prod 24: 165-172.

Meijer W. C. P. 1962. Das Balirind. A. Ziemsen Verslag, Wittenberg Lutherstandt. Meirelles FV, Rosa AJM, Garcia JM, Lobo RB, Smith LC, Duarte FAM. 1999. Is the American Zebu really a Bos indicus? Genet Mol Biol 22: 543-546.

Meyer K. 1992. Variance components due to direct and maternal effects for growth Traits of Australian beef cattle. Livest Prod Sci 31: 179204.

Mohamad K, Olsson M, van Tol HTA, Mikko S, Vlamings BH, Andersson G, Rodriguez-Martinez H, Purwantara BE, Paling RW, Colenbrander B, Lenstra JA. 2009. On the origin of Indonesian cattle. PLoS ONE 4 (5): e5490. http://doi.org/b65mtp

Mohapatra SC. 2004. Social and economic implications of biodiversity in livestock. In: Kornel, D, S.C. Mohapatra, S.P.S Alhawat, A .Tripathy (eds) Biodiversity of Livestock in Orissa and its role (2004). Swiss Agency for Development and Cooperation, New Delhi, India.

Moran J. 1985.Comparative performance of five genotypes of Indonesian large ruminants. 1. Effect of dietary quality on liveweight and feed utilization. Aust J Agic Res 36 (5): 743-752.

Mulder HA, Bijma P. 2005. Effects of genotype x environment interaction on genetic gain in breeding programs. J. Anim. Sci. 83: 49-61.

Munadi 2010.Potential and alternative development of Brebes typical Javanese cattle (Jabres).Proceedings of the National Seminar on Agribusiness Development Perspectives in Indonesia. Faculty of Animal Husbandry, Universitas Jenderal Soedirman, Purwokerto. [Indonesian]

Namikawa T. 1981. Geographic distribution of bovine Hemoglobin-beta 
(Hbb) alleles and the phylogenetic analysis of the cattle in Eastern Asia. Z Tierzuchtg Zuchtgsbiol 98 151-159.

Ngadiono N. 1995. Growth and Qualities of Carcass and Beef of Sumba Ongole, Brahman Cross and the Australian Commercial Cross intensively reared at Various Cut Weight. [Ph.D. Dissertation]. Bogor Agricultural University, Bogor. [Indonesian]

Nijman IJ, Otsen M, Verkaar E.L.C, Ruijter C.D, Hanekamp E et al. 2003. Hybridization of banteng (Bos javanicus) and zebu (Bos indicus) revealed by mitochondrial DNA, satellite DNA, AFLP and microsatellites. Heredity 90: 10-16.

Noor RR, Farajallah A, Karmita M. 2011. The purity test of Bali cattle by haemoglobin analysis using the isoelectric focusing method. J Hayati 8: $107-111$

Nozawa K. 1979. Phylogenetics studies on the native Domestic animals in East And Southeast Asia. Proceeding of Workshop Animals Genetics Resources in Asia and Oceania. Tsakuba, 3-7 September 1979. Society for the Advancement of Breeding Researches in Asia and Oceania (SABRAO) 23-43.

NRC [National Research Council]. 1983. Little-Known Asian Animals with a Promising Economic Future. National Academic Press, Washington, D.C.

Nugroho H. 2012. Productive Performances of PO cattle and its crosses at Small Holders Conditions at Different Altitudes of East Java.[PhD Dissertation]. Post Graduate Program in Animal Science. University of Brawijaya, Malang, Indonesia.

OAHAHP Pesisir Selatan District. 2012. Report of the Office of Agriculture, Horticulture, Plantation and Livestock of Pesisir Selatan district. Office of Agriculture and Horticulture, Animal Husbandry and Plantation, Pesisir Selatan District, Painan. [Indonesian]

Office of Animal Husbandry East Java Province. 2009. Animal Husbandry in Figures. Office of Animal Husbandry East Java Province, Surabaya. [Indonesian]

Okumura T, Saito K, Sakuma H, Nade T, Nakayama S, Fujita K, Kawamura T. 2007. Intramuscular fat deposition in principal muscles from twenty-four to thirty months of age using identical twins of Japanese Black steers. J Anim Sci 85 (8): 1902-1907.

Olori VE, Monwissen TH, Veerkamp H. 2002. Calving interval and survival breeding values as measure of cow fertility in a pasture-based production system with seasonal calving. J Dairy Sci 85 (3): 689-696. [Indonesian]

Omerling FJ. 1957. The Timor Problem. A Geographical Interpretation of an Underdeveloped.Island.2nd ed. J. B. Wolters, Groningen, Netherlands.

Pamungkas D, Antari R, Mayberry DE, Poppi DP. 2012. A Growth Comparison of Ongole and European Cross Cattle kept by Smallholder Farmers in Indonesia. Proceeding of the 15th AsianAustralian Animal Production (AAAP) Congress, Bangkok, Thailand, Bangkok, Thailand, November 2012.

Pane I. 1991. Produktivity and Breeding of Bali Cattle. Faculty of Animal Science, University of Hasanuddin, Ujung Pandang. [Indonesian]

Paputungan U, Hakim L, Ciptadi G, Lapian HNF. 2013. Polymorphism of growth hormone $M s p I$ enzyme-restriction associated with production performance of Ongole-Crossbred cattle mated by artificial insemination technique. J Basic Appl Sci Res 3 (6): 581-589.

Payne WJA, Hodges J. 1997. Tropical Cattle: Origin, Breeding and Breeding Policies. Blackwell Science, Oxford, UK,

Payne WJA, Rollinson DHL. 1973. Bali cattle. World Anim Rev 7: 13-21. Payne WJA. 1970. Cattle Production in the Tropics. Logman, London.

Pribadi LW, Maylinda S, Nasich M, Suyadi S. 2014. Prepubertal growth rate of Bali cattle and its crosses with Simmental breed at lowland and highland environment, IOSR J Agric Vet Sci 7 (2): 52-59.

Purnomoadi A, W. Bela, S. Dartosukarno. 2003. Eating behavior of Ongole crossbred and Limousin crossbred steers fed fermented rice straw and concentrate. Jurnal Ilmu Ternak dan Veteriner 8 (4): 276280

Purwoko A, Sutarno, Etikawati N. 2003. DNA polymorphism at locus-2 growth hormone gene of Madura cattle growth. Biodiversitas 4: 7-11.

Putra WPB, Hartatik T, Sumadi. 2013. Growth hormone gene genotyping by MspI restriction enzyme and PCR-RFLP methods in Aceh cattle breed at Indrapuri district of Aceh province. J Indon Trop Anim Agric 38 (4): 207-211.

Putra WPB, Hartatik T, Sumadi. 2014. Growth hormone genotyping by MspI restriction enzyme and PCR-RFLP method in Aceh cattle breed at Indrapuri District, Aceh Province, Indonesia. Biodiversitas 15: 1-5.

Putro P. 2009.Crossbreeding Impact on the Reproduction of Parent Offspring, Clinical Study Results. Workshop on Crossbreeding Cattle in Indonesia: Applications and Implications for Development of Cattle in Indonesia, Lustrum VIII, Faculty of Animal Science, Gadjah Mada University, Yogyakarta 8 August 2009. [Indonesian]

Qiu Q, Zhang G, Ma T, Qian W, Wang J et al. 2012. The yak genome and adaptation to life at high altitude. Nat Genet 44: 946-949.

Rahayu S, Susiati, Ciptadi G, Dikman DM. 2014. The MspI Polymorphism of the BMP-15 Gene in Indonesian PO Cattle. Res J Pharmaceut Biol Chem Sci 5 (2): 1832-1837.

Rahmawati SA, Harijani N, Lamid M. 2015. Analysis revenue of Madura and Madrasin cattle ranchers in the village of Taman Sereh, Sampang Sub-District. Agroveteriner 3 (2): 107-113. [Indonesian]

Ratnawati D, Rasyid A, Affandhi L.2008. The Capable Productivity of Imported and Derivative Dairy Cattle in East Java: Case Study in Low Land and Up Land of Pasuruan. Prosiding Semiloka Nasional Prospek Industri Sapi Perah Menuju Perdagangan Bebas-2020. Indonesia Research Central for Veterinary Science, Bogor, 21 April 2008. [Indonesian]

Regional Regulation of Bali Province No. 2/2003 about Expenditure of Bali Beef Cattle

Regulation of the Minister of Forestry of the Republic of Indonesia No. P.58/Menhut-II/2011 about: Strategy and Action Plan for Conservation of Banteng (Bos javanicus) in 2010-2020. [Indonesian]

Rocha JL, Baker JF, Womack JE, Sanders JO, Taylor JF. 1992. Statistical associations between restriction fragment length polymorphism and quantitative traits in beef cattle. J Anim Sci 70: 3360-3370.

Sahin A, Ulutas Z, Adkinson AY, Adkinson RW. 2012. Genetic and environmental parameters and trends for milk production of Holstein cattle in Turkey. Italian J Anim Sci 11 (e44): 242-248.

Saladin R. 1983. The Performance of Production and Reproduction Properties of Pesisir Selatan Local Cattle of West Sumatra.[Dissertation].School of Graduates. Bogor Agricultural University, Bogor. [Indonesian]

Samad MS, Soeradji.1990. General Animal Husbandry. CV. Yasaguna. Jakarta. [Indonesian]

Sarbaini. 2004. Study on Diversity of External Characteristics and DNA Microsatellite o Pesisir cattle, West Sumatra. [Ph.D. Dissertation].School of Graduates, Bogor Agricultural University, Bogor. [Indonesian]

Sariubang M. 1992. Feedloting system of Grati cattle. Sub Research Center for Animal Production Grati, Pasuruan. [Indonesian]

Schlee P, Graml R, Rottmann O, Pirchner F. 1994a. Influence of GrowthHormone genotypes on breeding values of Simmental Bulls. Zeitschrift fur Tierzuchtung und Zuchtungsbiologie 111: 253-256.

Schlee P, Graml R, Schallenberger E, Schams D, Rottmann O, Olbrichbludau A, Pirchner F. 1994b. Growth Hormone and insulin like growth Factor I concentrations in bulls of various growth hormone genotypes. Theor Appl Genet 88: 497-500.

Schutz MM, Freeman AE, Lindberg GL, Beitz DC. 1993. Effects of maternal lineages grouped by mitochondrial genotypes on milk yield and composition. J Dairy Sci 76: 621-629.

Schutz MM, Freeman AE, Lindberg GL, Koehler CM, Beitz DC, Bradley DG, Machugh DE, Cunningham P, Loftus RT. 1994. The effect of mitochondrial DNA on milk production and health of dairy cattle mitochondrial diversity and the origins of African and European cattle. Livest Prod Sci 37: 283-295.

Siregar AR. 1995. Potential and characteristics of Madura cattle. Jurnal Penelitian dan Pengembangan Pertanian 4 (2): -. [Indonesian]

Siregar SB, Tambing SN, Sitorus P. 1996. Efforts to accelerate increasing of beef cattle population through implementation of artificial insemination in Ciamis, West Java. Jurnal Penelitian Peternakan Indonesia 2 (2): 31-35. [Indonesian]

Siregar SB. 1996. Maintenance of Dairy Cow Lactation in Lowlands areas. Center for Agricultural Research and Development, Ministry of Agriculture, Bogor. [Indonesian]

Siswijono SB, Subagiyo I, Nurgiartiningsih VMA, Kusmartono, Hartutik, Tadjuddin. 2010. Perception of Madurese community on crossbreeding program of limousine and native Madura beef cattle in Madura Island of Indonesia. 9th World Congress on Genetics Applied to Livestock Production, Leipzig, Germany, August 1-6, 2010

Sodhi M, Mukesh M, Prakash B, Ahlawat SPS, Sobti RC. 2006. Microsatellite DNA typing for assessment of genetic variability in Tharparkar breed of Indian zebu (Bos indicus) cattle, a major breed of Rajasthan. Genetics 85: 165-170.

Soehadji. 2009. History of Milk industry. Directorate General of Agro and Chemical Industry, Ministry of Industry, Jakarta. [Indonesian]

Somarny WWMZ, Ruzainah, Aslinda A, K. Mohd. Hafiz AW, Md Tasol 
$S$ et al. 2015. MtDNA diversity and genetic lineages of four cattle breeds in Malaysia. Mal J Anim Sci 18 (1): 23-33

St John JC, Lloyd REI, Bowles EJ, Thomas EC, Shourbagy SE. 2004.The consequences of nuclear transfer for mammalian foetal development and offspring survival. A mitochondrial DNA perspective. Reproduction 127: 631-641

Sudarma IAI. 2013. Production Problems of Pastoral Livestock in East Nusa Tenggara. Graduate Program, University of Nusa Cendana, Kupang. [Indonesian]

Sudono A, Rosdiana F, Setiawan BS. 2003. Intensive Dairy Cattle Farming. Agromedia Pustaka. Jakarta. [Indonesian]

Sullivan GM, Diwyanto K. 2007. A Value Chain Assessment of the Livestock Sector in Indonesia. United States Agency for International Development, Washington DC.

Susilawati T, Subagyo I, Budiarto A, Ciptadi G, Kuswati. 2002. Phenotype and Genotype Identification of Local Breed for Conservation and Improvement Strategies of Local Cattle Production in East Java. Faculty of Animal Husbandry, Brawijaya University, Malang and Office of Livestock Production, East Java Province, Surabaya. [Indonesian]

Susilawati T. 2004. Local Cattle of Indonesia.[Research Report].Faculty of Animal Husbandry, Brawijaya University, Malang. [Indonesian]

Susilorini. 2010. Farming of 22 Potential Livestock. Penebar Swadaya, Jakarta. [Indonesian]

Sutarno, Cummins JM, Greeff J, Lymbery AJ. 2002a. Mitochondrial DNA polymorphisms and fertility in beef cattle. Theriogenology 57: 16031610 .

Sutarno, Junaidi A, Purwoko A, Lelana NI. 2012. Identification and characterisation of the polymorphic growth hormone gene of the Bali cattle, the Madura cattle and Ongole cattle. Biodiversitas 3 (1): 169 173.

Sutarno, Junaidi A, Tapa B. 2003 Selection to Acquire Local Beef of Indonesia, which Superior in Meat Production (growth) through a Selection based on the Gene Markers of Growth Hormone Gene. Reports of RUT-VIII, Research Institute, University of Sebelas Maret, Surakarta. [Indonesian]

Sutarno, Junaidi A, Tappa B. 2002b. Growth hormone gene variations and meat production (growth) of Indonesian local cattle. Proceeding of the 3rd International Seminar on Tropical Animal Production, October 15-16, 2002, Faculty of Animal Science, Gadjah Mada University, Yogyakarta.

Sutarno, Junaidi A. 2001. Identification and characterization of bovine growth hormone gene and mitochondrial DNA variations of Indonesian native cattle. Proceeding of ITSF One Day Seminar on Science and Technology January 29 th 2001, Hilton International Hotel, Jakarta.

Sutarno, Lymbery AJ, Thompson RCA, Cummins JM. 1996. Associations Between Growth Hormone Genotypes and Estimated Breeding Values for Pre weaning Growth of Beef Cattle. Proceeding of the 13th International Congress on Animal Reproduction, Darling Harbour Convention Centre, Sydney, Australia, June 30-July 4, 1996.

Sutarno, Setyawan AD, Lymbery AJ. 2015. Genetic diversity of five Indonesian native cattle breeds at microsatellite loci. Asian J Anim Sci 9: 57-64.

Sutarno, Setyawan AD. 2015. Diversity of local Indonesian cattle and effort to development the superior cattle. International Conference of Biodiversity and Sustainable Industry, University of Sebelas Maret, Surakarta, 5-6 November 2015.

Sutarno. 1998. Candidate Gene Marker for Production Traits in Beef Cattle. [Ph.D. Dissertation], Murdoch University, Perth, Australia

Sutarno. 2003. Selection for obtaining Local Beef Cattle of Indonesia types of Benggala that Superion in Meat Production through Molecular Genetic Technology. Final Research Reports of RUT-IX, Research Institute, Sebelas Maret University, Surakarta. [Indonesian]

Sutarno. 2006. Use of Molecular Techniques for Improving Nature of Animal Production. Inaguration of Professorship speech in the field of Molecular Genetics, Faculty of Mathematics and Natural Sciences, University of Sebelas Maret in the Senate Open Meeting of University of Sebelas Maret, on March 18, 2006. [Indonesian]

Sutarno. 2010. Genetic variation among Indonesian native cattle breeds based on polymorphisms analysis in the growth hormone loci and mitochondrial DNA. Biodiversitas 11: 1-5.

Suwiti NK, Rantam FA, Besung INK. 2008. Detection of the class I and class II proteins of bovine major histocompatibility complex in Madura cattle. Jurnal Veteriner 9 (3): 147-151. [Indonesian]

Suyadi S, Hakim L, S. Wahjuningsih, H. Nugroho. 2014. Reproductive performance of Peranakan Ongole (PO)-and Limousin x PO Crossbred (Limpo) cattle at different altitude areas in East Java, Indonesia. J Appl Sci Agric 9 (11): 81-85

Syarif EK, Harianto B. 2011. Farming and Business of Dairy Cattle. Agromedia Pustaka, Jakarta. []Indonesian]

Talib C, Entwistle K, Siregar A, Budiarti-Turner S, Lindsay D. 2002. Survey of population and production dynamics of Bali cattle and existing breeding programs in Indonesia. In: Proceeding of an ACIAR Workshop on Strategies to Improve Bali Cattle in Eastern Indonesia, Denpasar, Bali, Indonesia.

Tang G, Stewart J, Plastow G, Moore S, Wang Z. 2011. Optimizing a beef production system using specialized sire and dam lines. Can J Anim Sci 91: 353-361

Tavirimirwa B, Mwembe R, Ngulube B, Banana NYD, Nyamushamba GB, Ncube S, Nkomboni D. 2013. Communal cattle production in Zimbabwe: A review. Livest Res Rural Dev 25 (12). http://www.lrrd.org/lrrd25/12/tavi25217.htm. [2 October 2015]

Tempo 27.06.2013. Thousands of Cattle Disturb Banteng Habitat in Baluran. http://nasional.tempo.co/read/news/2013/06/27/206491636/ribuansapi-ganggu-habitat-banteng-baluran [2 October 2015]

Tenaya IWM. 2010. Studies of the pathogenesis of Jembrana disease virus infection in Bos javanicus [Ph.D. Dissertation]. Murdoch University, Perth, Australia.

Toelihere MR. 1981. Artificial Insemination in Livestock. P.T. Angkasa, Bandung. [Indonesian]

Turner HL. 1977. The Tropical Adaptation of Beef Cattle an Australian Study. In: Animal Breeding: Selected Articles from The World Animal Review. FAO Animal Production and Health Paper 1: 92-97.

Umar S. 2009. Potential of Oil Palm Plantations for Development Centre of Beef Cattle in Revitalizes and Accelerate Sustainable Development of Animal Husbandry. Inauguration of Professorship speech in the field of Animal Reproduction Science, Faculty of Agriculture, University of North Sumatra, Medan. [Indonesian]

Utomo B, Oelviani R, Subiharta. 2015. Enhancing perfomance of weaned Ongole calf through management improvement using local resources. Pros Sem Nas Masy Biodiv Indon 1: 838-842. [Indonesian]

Uzzaman MR, Bhuiyan MSA, Edea Z, Kim KS. 2004. Semi-domesticated and Irreplaceable Genetic Resource Gayal (Bos frontalis) Needs Effective Genetic Conservation in Bangladesh: A Review. Asian Austr J Anim Sci 27 (9): 1368-1372

Verkaar ELC, Nijman IJ, Boutaga K, Lenstra JA. 2002. Differentiation of cattle species in beef by PCR-RFLP of mitochondrial and satellite DNA. Meat Sci. 60: 365-369.

Vigne JD. The origins of animal domestication and husbandry: A major change in the history of humanity and the biosphere. C R Biol 334: 171-181.

Widi TSM, Udo HMJ, Oldenbroek K, Budisatria IGS, Baliarti E, van der Zijpp AJ. 2013. Unique cultural values of Madura cattle: is Crossbreeding a threat? Anim Genet Resour. DOI: $10.1017 /$ S2078633613000349

Wijono DB, Bambang S. 2004. Potential and Diversity of Genetic Resources of Madura Cattle.National Workshop on Beef Cattle.Livestock Research Center, Pasuruan. [Indonesian]

Wilcox G.E, Chadwick B.J, Kertayadnya G. 1995. Recent advances in the understanding of Jembrana disease. Vet Microbiol 46: 249-255.

Wilcox GE, Kertayadnya G. Hartaningsih N. Dharma DMN, Soeharsono S, Robertson T. 1992. Evidence for viral aethology of Jembrana disease in Bali cattle. Vet Microbiol 33: 367-374.

Williamson G, Payne WJA. 1980. An introduction to animal husbandry in the tropics. Tata McGrow-Hill Pub.Co.Ltd, New Delhi, India.

Winaya A, Muladno, Gurnadi RE, Saefuddin A. 2009. Y chromosome microsatellites variation in Bali cattle (Bos sondaicus) population. Anim Prod 11 (3): 149-154.

Winkelmann DC, Querengesser LD, Hodgetts RB. 1990. Growth hormone restriction fragment length polymorphisms that segregate with 42-day live weight mice. Genome 33 (2): 235-239.

Wirdahayati RB. 1994. Reproductive characteristics and productivity of Bali and Ongole cattle in Nusa Tenggara, Indonesia. [Ph.D. Dissertation].Depatment of Farm Ainmal Medicine and Production.The University of Queensland, Brisbane, Australia.

Wirdahayati RB. 2010. The application of technology to improve productivity of beef cattle in East Nusa Tenggara. Wartazoa 20 (1): 12-20. [Indonesian]

Wiyatna MF, Gurnadi E, Mudikdjo K. 2012. Productivity of Peranakan Ongole cattle on the community husbanry in Sumedang District. Jurnal Ilmu Peternakan 12 (2): 22-25. [Indonesian] 
Yeates NT, Schmidt PJ, Young JS. 1975. Beef Cattle Production Butterworths Pty. Limited, Brisbane.

Yulyanto CA, Susilawati T, Ihsan MN. 2014. Reproductive performance of Peranakan Ongole (PO) and Limousin Crossbreeds cattle in the sub-district Sawoo, Ponorogo and sub-district Tugu, Trenggalek. Jurnal Ilmu-Ilmu Peternakan 24 (2): 49-57. [Indonesian]

Yunita ARE. 2012. Existence of Peunuwo Meugang by New Bride in the village of Nigan, Seunagan sub-District, Nagan Raya. Studies
Program of Anthropology Education, State University of Medan, Medan. [Indonesian]

Zardoya R, Meyer A. 1996. Phylogenetic performance mitochondria protein coding genes in resolving relationship among vertebrates. Mol. Biol. Evol. 13: 933-942.

Zulkharnaim, Jakaria, Noor RR. 2010. Identification of genetic diversity of growth hormone receptor (GHR/Alu I) gene in Ba li cattle. Media Peternakan 33: 81-87. 